\title{
Exocytosis in Astrocytes
}

\author{
Aleksandra Mielnicka and Piotr Michaluk *(i) \\ BRAINCITY, Laboratory of Neurobiology, The Nencki Institute of Experimental Biology, PAS, \\ 02-093 Warsaw, Poland; a.mielnicka@nencki.edu.pl \\ * Correspondence: p.michaluk@nencki.edu.pl; Tel.: +48-22-5892-382
}

\begin{abstract}
Until recently, astrocytes were thought to be a part of a simple "brain glue" providing only a supporting role for neurons. However, the discoveries of the last two decades have proven astrocytes to be dynamic partners participating in brain metabolism and actively influencing communication between neurons. The means of astrocyte-neuron communication are diverse, although regulated exocytosis has received the most attention but also caused the most debate. Similar to most of eukaryotic cells, astrocytes have a complex range of vesicular organelles which can undergo exocytosis as well as intricate molecular mechanisms that regulate this process. In this review, we focus on the components needed for regulated exocytosis to occur and summarise the knowledge about experimental evidence showing its presence in astrocytes.
\end{abstract}

Keywords: SNARE; secretion; vesicles; transmitter; lysosome; gliotransmission

\section{Introduction}

Astrocytes, together with oligodendrocytes and microglia, form three main categories of glial cells in the central nervous system. They are found throughout the brain and occupy around half of the brain's volume. Astrocytes have a bushy morphology with few main processes, starting from a relatively small cell body and extending many fine processes that invade extracellular space. It has been estimated that an astrocyte can contact over 100,000 synapses in rats and almost two million in the human cortex [1]. Even though astrocytes tend to occupy distinct and non-overlapping domains, their fine processes are in contact with one another via gap junctions. They create, therefore, a large network of interconnected cells which can easily exchange ions and small molecules of up to $1-1.2 \mathrm{kDa}$ [2].

For a long time, neuroscientists considered glia as merely supportive cells in the brain

Received: 16 August 2021

Accepted: 14 September 2021

Published: 16 September 2021

Publisher's Note: MDPI stays neutral with regard to jurisdictional claims in published maps and institutional affiliations. that control ion and water homeostasis, produce and remove neurotransmitters, induce synaptogenesis, provide trophic factors for neurons and maintain the blood-brain barrier. Their view as "passive" cells was reinforced by observations that astrocytes expressed potassium and sodium channels and could exhibit evoked inward currents, but they did not "fire" or propagate action potentials [3]. Therefore, it can be safely said that the entire field was revolutionised by the discovery of glutamate-induced $\mathrm{Ca}^{2+}$ waves in cultured astrocytes. This raised the possibility that astrocytes may contribute to modulating neuronal activity [4]. This observation was later confirmed many times in different in vitro and in vivo models [5-9]. Further demonstrations that intracellular $\mathrm{Ca}^{2+}$ levels in astrocytes can cause a release of glutamate and a subsequent $\mathrm{Ca}^{2+}$ increase in neurons $[10,11]$ led to the concept of gliotransmission i.e., the release of transmitters from astrocytes and other glial cells to neurons. This, in turn, helped to coin the term "tripartite synapse", where astrocyte processes form an integral part of a functional brain connection in addition to pre- and post-synaptic compartments [12]. The classical understanding of this model assumes that through spillover neurotransmitters and other factors released by neurons, bind to high-affinity astrocytic $G$ protein-coupled receptors (GPCRs), triggering inositol-1,4,5trisphosphate $\left(\mathrm{IP}_{3}\right)$ production and $\mathrm{Ca}^{2+}$ release from the endoplasmic reticulum (ER) [13]. 
Increases in astrocytic $\mathrm{Ca}^{2+}$ levels lead to a release of gliotransmitters, including glutamate, ATP, D-serine and $\gamma$-aminobutyric acid (GABA) [14]. The release of gliotransmitters has a wide range of effects on neurons, such as stimulating N-methyl-D-aspartate receptor (NMDAR), synchronising neuronal spiking [15], as well as regulating synaptic vesicle release probability, synaptic plasticity and even behaviour $[7,14,16-18]$. Despite this description of different modes of transmitter release from astrocytes, regulated exocytosis became the most studied but also criticised (for a review, see [7,19,20]).

Exocytosis is a process in which the cargo of a secretory vesicle is released across the cell membrane. This universal process, which is common to all eukaryotic cells, can be generally divided into two types: unregulated and regulated exocytosis. Unregulated (constitutive) exocytosis typically involves the formation of membranous secretory vesicles within the cell, in which the cargo is packaged and then continually released through the cell membrane. In regulated exocytosis, the secretory vesicle with its cargo is stored until a signal triggers the process of secretion [21-23]. The secretory vesicle has to go through several stages before secretion actually occurs. The first stage, docking, is the tethering and linking of the vesicle to the plasma membrane. Docking is followed by priming, during which the attached vesicle's membrane is brought in proximity to the release site at the plasma membrane. Finally, a trigger (most commonly an influx of $\mathrm{Ca}^{2+}$ ) leads to fusion, during which the vesicle and the plasma membrane combine with each other. After fusion, the secretory vesicle can either be recycled by the closing of the fusion pore, a model termed "kiss-and-run", or it can collapse and fully integrate with the plasma membrane [21,24]. Regardless of the mechanism of exocytosis, all cells require vesicular organelles with a cargo and the molecular machinery to conduct exocytosis.

Similar to all eukaryotic cells, astrocytes contain different types of vesicular organelle which cargo can be released to the environment. Generally, secretory vesicles form a complex network originating from the ER or the Golgi apparatus, as well as from endosomes. Astrocytes are not different, and they contain several secretory organelles, including synaptic-like microvesicles (SLMV) [25-28], dense-core vesicles (DCV) [29-32], secretory lysosomes (SL) [33-35] and extracellular vesicles, which can be further divided into exosomes and ectosomes [36,37]. Out of these, the SLMVs, DCVs and SLs have been well described in the literature as undergoing exocytosis in astrocytes (see Table 1). In this review, we focus on these three types of vesicular organelle, and the molecular machinery regulating exocytosis and providing its spatial organisation, as well as on the $\mathrm{Ca}^{2+}$ sensors which can trigger membrane fusion.

Table 1. Secretory vesicles undergoing exocytosis in astrocytes.

\begin{tabular}{|c|c|c|c|c|}
\hline \multirow{2}{*}{ Secretory Organelle } & \multirow{2}{*}{ Diameter } & \multirow{2}{*}{ Cargo } & \multicolumn{2}{|c|}{ Associated Proteins } \\
\hline & & & Protein Name & Gene Name \\
\hline \multirow{7}{*}{$\begin{array}{c}\text { Synaptic-Like } \\
\text { Microvesicles (SLMVs) }\end{array}$} & \multirow{7}{*}{$30-100 \mathrm{~nm}$} & \multirow{7}{*}{$\begin{array}{l}\text { Glutamate } \\
\text { d-serine }\end{array}$} & VGluT1 & Slc17a7 \\
\hline & & & VGlut2 & Slc17a6 \\
\hline & & & VGlut3 & Slc17a8 \\
\hline & & & VAMP2 (synaptobrevin 2) & Vamp2 \\
\hline & & & VAMP3 (cellubrevin) & Vamp3 \\
\hline & & & Rab3a & Rab3a \\
\hline & & & V-ATPase & Atp6v0, Atp6v1 ${ }^{1}$ \\
\hline \multirow{6}{*}{$\begin{array}{l}\text { Dense-Core Vesicles } \\
\text { (DCV) }\end{array}$} & \multirow{6}{*}{$100-600 \mathrm{~nm}$} & ANP & & \\
\hline & & ATP & & \\
\hline & & BDNF & VAMP2 (synaptobrevin 2) & Vamp2 \\
\hline & & Secretogranin II & VAMP3 (cellubrevin) & Vamp3 \\
\hline & & Secretogranin III & VNuT & Slc17a9 \\
\hline & & $\begin{array}{c}\text { Chromogranin } \\
\text { NPY }\end{array}$ & & \\
\hline
\end{tabular}


Table 1. Cont.

\begin{tabular}{|c|c|c|c|c|}
\hline \multirow{2}{*}{ Secretory Organelle } & \multirow{2}{*}{ Diameter } & \multirow{2}{*}{ Cargo } & \multicolumn{2}{|c|}{ Associated Proteins } \\
\hline & & & Protein Name & Gene Name \\
\hline \multirow{6}{*}{$\begin{array}{l}\text { Secretory Lysosome } \\
\text { (SL) }\end{array}$} & \multirow{6}{*}{$300-500 \mathrm{~nm}$} & & VAMP7 (TI-VAMP) & Vamp7 \\
\hline & & ATP & Rab7 & Rab7a \\
\hline & & Cathepsin B & CD63 & Cd63 \\
\hline & & Cathepsin D & LAMP1 & Lamp1 \\
\hline & & Proteolytic enzymes & Sialin & Slc17a5 \\
\hline & & & VNuT & Slc17a9 \\
\hline
\end{tabular}

${ }^{1}$ V-ATPase is a large complex consisting of 13 subunits coded by many more genes; however, all the gene names start with Atp6v0 or with Atp6v1 for the $V_{O}$ and $V_{1}$ domains, respectively.

\subsection{Synaptic-like Microvesicles (SLMVs)}

Astroglial SLMVs are small (30-100 $\mathrm{nm}$ in dimeter) electron-lucent vesicles, similar to neuronal synaptic vesicles. They were first identified in the brain tissue in the molecular layer of the dentate gyrus using electron microscopy [25]. They are much less numerous than synaptic vesicles in neurons; however, they form small groups of 2-15 in the astrocytic cytoplasm and were shown to be present in the vicinity of NMDARs at asymmetric synapses $[25,38,39]$. Further studies have also found astrocytic SLMVs close to extrasynaptic NMDARs containing the GluN2B subunit [26]. Despite being grouped, SLMVs in astrocytes are not concentrated by structurally organised active zones, as it is the case in neurons [26]; however, the endoplasmic reticulum (ER) seems to be in proximity to these clusters [25,38]. This localisation is in line with the canonical tripartite synapse model, where local increases in $\mathrm{Ca}^{2+}$ concentration released from the ER can trigger a release of gliotransmitters. It should be noted, however, that ER is usually not present in perisynaptic processes [40]. Additionally, it was shown that SLMVs containing vesicle-associated membrane protein 2 (VAMP2) are highly mobile in astrocytes, and that an increase in cytosolic $\mathrm{Ca}^{2+}$ causes vesicle docking [29]. Similarly, $\mathrm{Ca}^{2+}$-regulated mobility of vesicular glutamate transporter 1 (VGluT1)-positive vesicles have been found also in other studies [41].

SLMVs contain mainly small signalling molecules: glutamate and D-serine [37]. Filling vesicles with a transmitter requires active transport fuelled by an electrochemical gradient generated by the vesicular ATP-dependent $\mathrm{H}^{+}$pump (V-ATPase), a large complex composed of two domains, $\mathrm{V}_{\mathrm{O}}$ (transmembrane, responsible for $\mathrm{H}+$ translocation) and $\mathrm{V}_{1}$ (responsible for ATP hydrolysis) [23]. Expression of V-ATPase has been shown in cultured astrocytes by fractionation and immunoblotting [27,42], immunofluorescence [43] and functionally, by usage of its blocker-bafilomycin [44-46]. The transport of a neurotransmitter is mediated by vesicular transporters. There are three vesicular glutamate transporters (VGluT13 ) and they all have been identified in cultured astrocytes [25,27,29,33-35,45,47-49]. Moreover, expression of VGluT1 and -3 has been demonstrated in acute and fixed tissue by a number of techniques, including confocal and electron microscopy, and RT-PCR [25,39,46,50,51]. Electron microscopy studies have shown that VGluT1-3 colocalises with SLMVs in the hippocampus $[25,39,51]$ and, importantly, in the case of VGluT1 and -3 , immunogold labelling was not present in knockout animals of those proteins [39,51]. Additionally, Bezzi and co-workers [25], by means of immunogold staining, have shown coloclization of VGluT1 and -2 with VAMP3. Notably, other studies have not confirmed the expression of VGluTs in astrocytes by means of RNA-seq [52,53], gene chip microarrays [54], or by confocal microscopy [55]. It has to be noted, however, that high-throughput methods such as RNA sequencing or gene chip microarrays might not be sensitive enough to detect low protein expression, and that because reported exocytosis in astrocytes is slow and glutamate is also a metabolite for astrocytes, they might not need high expression of VGluTs [56,57].

So far, no D-serine vesicular transporter has been identified in astrocytes in situ; however, it was shown to be present in immunopurified astrocytic vesicles in one study [27]. The identified transporter was proposed to be the D-serine/chloride co-transporter, which uses the $\mathrm{H}^{+}$gradient created by V-ATPase concentrated D-serine in the vesicles [27]. It is 
still not clear whether D-serine is loaded together with glutamate to the same SLMVs. This process of vesicular synergy is present in neurons where glutamate is co-released with dopamine, serotonin or acetylcholine [58]. VGluTs and D-serine are located in astrocytic VAMP2- and VAMP3-positive vesicles, which raises the possibility that these may be the same vesicles $[25,45,49,59,60]$. Additionally, in immunopurified SLMVs, both transmitters can be present within the same vesicle, and D-serine application modulates the uptake of glutamate to immunopurified SLMVs and vice versa [27]. This suggests that these two amino acids may be released from the same vesicles. Notably, D-serine had no effect on glutamate uptake into immunopurified synaptic vesicles [27]. Contrary to this evidence, in fixed tissue, it was shown that D-serine and glutamate are stored in distinct vesicles within the same astrocyte [38]. Notably, it has also been recently shown that the source of D-serine is mainly neuronal, as serine racemase (SR) - the enzyme which converts L-serine into D-serine-is expressed almost entirely in the neurons [61,62]. This, however, does not exclude the possibility of D-serine transport from neurons to astrocytes and secondary astroglial release of D-serine [63]. Additionally, traumatic brain injury causes a population of reactive astrocytes to express SR, so astroglial D-serine may be important in pathological conditions [64].

\subsection{Dense-Core Vesicles (DCV)}

Dense-core vesicles (DCVs) have been well studied in a variety of tissues, where they are responsible for the storage and secretion of biogenic amines, peptides and neurotrophins, including catecholamines released from adrenal chromaffin cells or insulin released from DCVs in pancreatic $\beta$ cells [21]. In astrocytes, DCVs are larger than SLMVs, being 100-600 nm [30-32] in diameter; however, it has been reported that atrial natriuretic peptide (ANP)-containing vesicles can be $50 \mathrm{~nm}$ in diameter [65]. As their name suggests, DCVs have an electron-dense core, although it is not as dense as that in neuroendocrine cells $[36,65]$. DCVs are not very abundant in astrocytes, accounting for roughly $2 \%$ of the vesicles [29]. Despite their low numbers, they have been shown in culture to contain an array of molecules such as secretogranin II [30,31,66,67] and III [68,69], chromogranins [32], ANP [66,70,71], neuropeptide Y (NPY) [31,72], brain-derived neurotrophic factor (BDNF) $[73,74]$ and ATP $[75,76]$. To our knowledge, only secretogranins consisting of DCVs have been shown to be present in situ in human brain tissue [32]. Interestingly, the same study showed the existence of inositol-1,4,5-triphosphate $\left(\mathrm{IP}_{3}\right)$ receptors $\left(\mathrm{IP}_{3} \mathrm{Rs}\right)$ in DCVs, suggesting that they can serve as $\mathrm{IP}_{3}$-sensitive intracellular $\mathrm{Ca}^{2+}$ reservoirs. As they are relatively small, they could be directed to many distinct processes of the astrocyte, including perisynaptic processes [32], and provide an additional source of $\mathrm{Ca}^{2+}$ for regulated exocytosis. Similar to SMLVs, DCVs have also been found to be highly mobile, and an increase in cytosolic $\mathrm{Ca}^{2+}$ levels seems to decrease this mobility $[77,78]$.

Of all molecules present in DCVs, ATP has attracted the most attention, as it is a potent transmitter influencing glial and neuronal signalling, as well as behaviour $[79,80]$. Its localisation in DCVs in cultured astrocytes was demonstrated on a few occasions [74-76] but, to our knowledge, not in the tissue. ATP is transported into vesicles by the vesicular nucleotide transporter (VNuT) [81], which is also present in microglia [82]. VNuT is present in cultured astrocytes [47,83-85] as well as in freshly isolated astrocytes [86]. Even though there seems to be a lack of evidence showing VNuT in the astrocytes in tissue, an astrocyteselective VNuT knockout was shown to be important for fluoxetine-induced antidepressive behaviour [87]. This provides proof, albeit indirect, that ATP is transported into the vesicles in astrocytes in vivo.

\subsection{Secretory Lysosomes (SL)}

Secretory lysosomes have diameters ranging from 300 to $500 \mathrm{~nm}[34,88]$ and have been identified multiple times in cultured astrocytes or in freshly isolated astrocytes, where they store and release ATP in a $\mathrm{Ca}^{2+}$-dependent manner $[34,35,89]$. Moreover, lysosomes can coexist with SLMVs in the same astrocyte, and they fuse with the plasma 
membrane in a $\mathrm{Ca}^{2+}$-regulated manner, although small vesicles are exocytosed more efficiently than lysosomes [33]. Secretory lysosomes contain ATP, cathepsin B and D and other proteolytic enzymes $[34,37,90,91]$. Secretory lysosomes in cultured astrocytes can be labelled by dextrans [92,93], various FM dyes and MANT-ATP—a fluorescent analogue used in studies of ATP stores [34,94] - as well as quinacrine, which emits a green fluorescent signal in the presence of intracellular ATP [91]. One study has found, however, that FM dyes do not enter astrocytes on the endocytic pathway but rather via the store-operated calcium channel and do not stain lysosomes [95]. In this study, the authors did not use any lysosomal/endosome markers except for fluorescently labelled dextran. Astroglial secretory lysosomes lack VGluTs, VAMP2 and VAMP3 [33,34]; however, they express lysosomal-specific markers including cathepsin D, lysosomal-associated membrane protein 1 (LAMP1) [34,59], sialin, CD63/LAMP3 [35], monomeric ras-related protein Rab7 [96] and VAMP7 [35]. Interestingly, VAMP7 is insensitive to cleavage by the tetanus neurotoxin (TeNT) and contributes to TeNT-independent exocytotic release of ATP, hence its alternative name (TI-VAMP) [33,91]. Downregulation of VAMP7 expression inhibits the fusion of ATPstoring vesicles and decreases ATP-mediated calcium wave propagation [91], which is an important form of long-range communication in the astrocytic network. Similar to DCV, secretory lysosomes in the astrocytes express VNuT [83], which transports ATP from the cytoplasm into the vesicles.

\section{The Exocytosis Machinery in Astrocytes}

Secretory vesicle docking, priming and fusion with a plasma membrane are generally mediated by SNARE proteins (soluble N-ethylmaleimide-sensitive fusion protein attachment protein receptors) and SM proteins (Sec1/Munc18-like proteins) that undergo a cycle of association and dissociation during the fusion reaction. The mechanism of regulated SNARE complex assembly is conserved in many different cell types, including neuronal, exocrine, haematopoetic and endocrine cells (Figure 1; for reviews, see [21,23,97-99]). The SNARE complex consists of two target membrane proteins (t-SNARE), namely syntaxin and SNAP-25 (or SNAP-23), and one vesicle-associated (v-SNARE) protein, VAMP2. Syntaxins are $\sim 35 \mathrm{kDa}$ proteins containing a carboxy-terminal transmembrane domain and an amino terminus oriented toward the cytoplasm. The other t-SNARE, SNAP-25 or -23 ( 25 and $23 \mathrm{kDa}$ respectively), is attached to the plasma membrane via four palmitoylated cysteine residues. The v-SNARE VAMP2 is a $18 \mathrm{kDa}$ protein with a vesicle lumen-oriented carboxyl terminus and an amino terminus oriented toward the cytoplasm. During the vesicle docking process, the SM protein Munc18-1 initially binds to the closed conformation of syntaxin1. When the closed conformation of syntaxin1 "opens" during priming and SNARE complexes starts forming, Munc18-1 remains attached to syntaxin1 in the assembling SNARE complex but switches its binding mode to an interaction with the SNARE complex. The SNARE complex is extremely stable, where one v-SNARE binds with two tSNARE proteins in a 1:1:1 ratio. The SNARE complex forms initially a "trans" configuration (SNARE proteins are on opposite membranes) with amino- to carboxy-terminal zippering of proteins, which brings the vesicle closer to the plasma membrane. Assembly of the full trans-SNARE complex, together with the action of the SM protein, opens the fusion pore. After fusion pore opening, the membrane of the vesicle and the plasma membrane completely merge, and trans-SNARE complexes are converted into cis-SNARE complexes, where the SNARE complexes are on a single membrane. Next, the cis-SNARE complex proteins are bound by N-ethylmaleimide sensitive factor (NSF) and soluble NSF-attachment proteins (SNAPs, no relation to SNAP-25 and its homologs) to catalyse SNARE complex dissociation into monomers. This allows for endocytosis of the v-SNARE and recycling of the individual $\mathrm{t}$-SNAREs back to their respective plasma membrane compartments. 


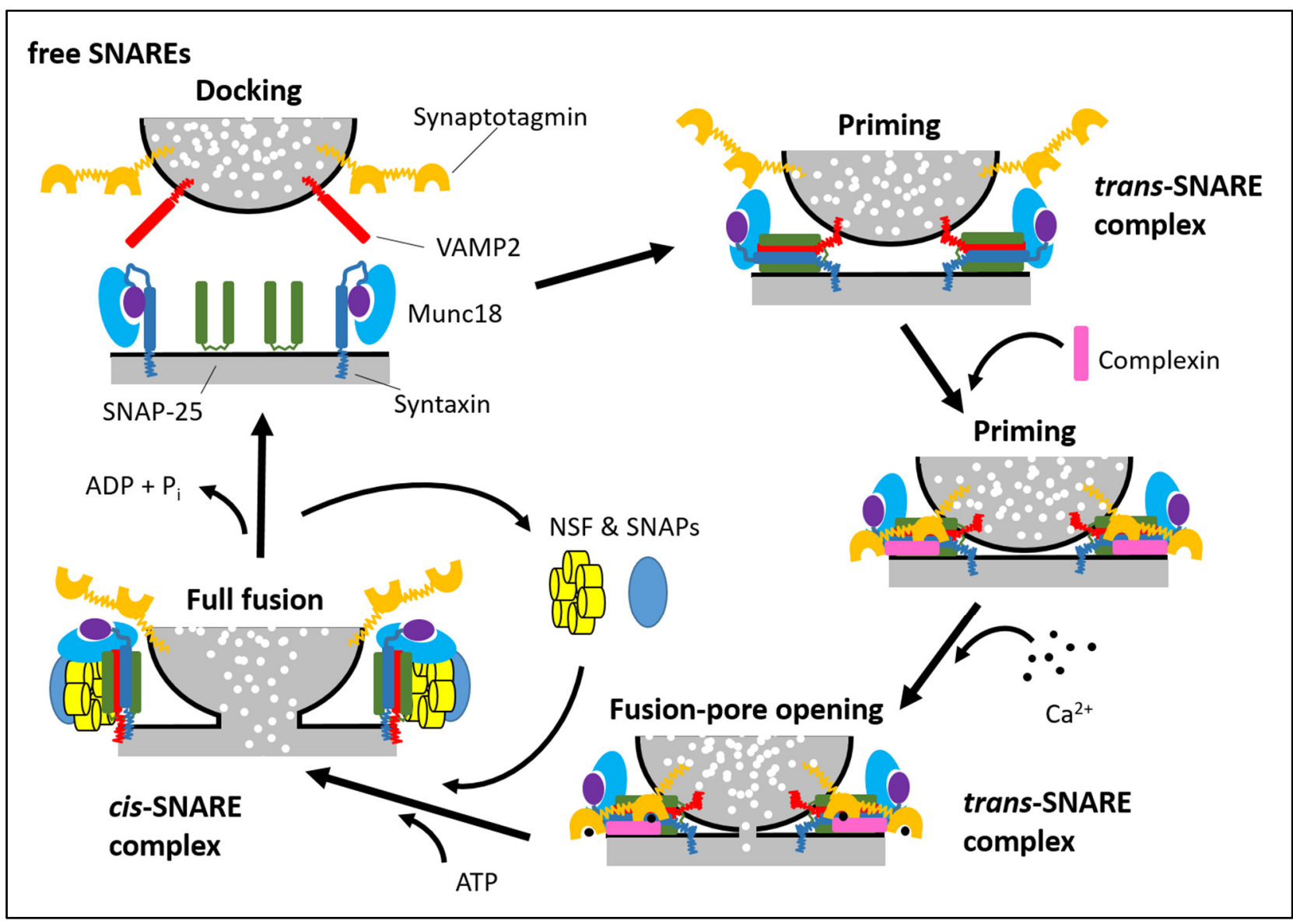

Figure 1. Schematic SNARE/SM cycle. SNARE and SM proteins undergo a cycle of assembly and disassembly. At the beginning of docking, syntaxin1 is present in a "closed" conformation in which its Habc domain (purple) blocks its SNARE motif (dark blue rectangle). In this position, Munc18-1 binds monomeric syntaxin1. For the SNARE complex to assemble, syntaxin1 has to "open". During this conformational change, the SNARE complex assembly and Munc18-1 change their binding to syntaxin1 by binding to assemble the trans-SNARE complexes via interacting with the syntaxin1 N-peptide. Once the SNARE complexes have partly assembled, complexin binds to further tighten secretory vesicle priming. The "superprimed" SNARE/SM protein complexes are then ready for the $\mathrm{Ca}^{2+}$-trigger. $\mathrm{Ca}^{2+}$ binds to synaptotagmin, which causes an interaction between synaptotagmin and SNAREs and phospholipids of the plasma membrane. After fusion pore opening, the vesicular membrane and plasma membrane merge, resulting in a change from trans- to cis-SNARE complexes. The association of NSF/SNAP ATPases disassembles SNARE complexes to free SNAREs, and the vesicle is recycled, can be refilled with neurotransmitters, and reused for another release (modified from [98]).

For over two decades, a large number of studies identified components of the SNARE complex and SM proteins in the astrocytes; however, the issue of regulated exocytosis still remains a matter of debate. Out of the v-SNAREs, the expression of VAMP2 and VAMP3 has been shown multiple times in vitro [29,45,100-102] and in vivo [43,46,52-54,103].

The functionality of VAMP2/VAMP3 has been confirmed by multiple studies, especially by the use of tetanus neurotoxin (TeNT) and botulinum neurotoxin (BoNT), which cleave SNARE proteins. In particular, application of TeNT to cultured astrocytes attenuated the exocytotic release of glutamate [25,45,104-106]. Moreover, the enzymatically active light chain of TeNT was applied through a patch pipette to astrocytes in acute slices, where it abolished the release of D-serine [16] or glutamate [26,107], which affected neighbouring neurons. Importantly, Haydon's laboratory has developed a transgenic mouse which overexpress a dominant negative SNARE (cytosolic tail of VAMP2, dnSNARE) in astrocytes [17]. This method had been previously shown to decrease astrocytic gliotransmission in vitro [46] and was later explained in detail as stabilizing the fusion pore in a narrow, release-unproductive state, thus effectively decreasing exocytosis [73]. Experiments 
with dnSNARE transgenic mice performed not only by Haydon's group showed reduced SNARE-dependent gliotransmission (mostly of adenosine and ATP), which influences the behaviour, synaptic transmission and maturation of neurons [17,86,108-113]. Although studies using dnSNARE mice were convincing and showed the transgenic expression specifically in astrocytes, a study by Fujita and co-workers [114] found that dnSNARE can be also expressed in the neurons of transgenic mice, thus questioning the previous findings. This has led to a heated debate (see $[115,116])$. The discussion has pointed to technical matters in studying gliotransmission, particularly the use of the GFAP promoter as a glial-specific promoter. Importantly, another study using astrocyte-specific expression of the BoNT serotype B light chain (BoNT/B) in a Cre/Lox system (named "iBot mice") showed decreased VAMP-dependent glutamate release from the astrocytes and impaired glial volume regulation [117]. Later, the same model (iBot mice) was used in parallel with dnSNARE mice to show that blockade of gliotransmitter release from astrocytes influences adult-born neurons, reduces their glutamatergic synaptic input as well as dendritic spine density, and leads to their lower functional integration and hence survival [110]. This result validated the relevance of the dnSNARE mouse model, as well as the importance of astrocytic exocytosis.

Other v-SNARE proteins have also been identified in astrocytes. In particular, VAMP7 was shown in astrocytes in vitro as a v-SNARE associated with lysosomes [35,59,91], as was VAMP8 [35,59]. Additionally, VAMP4 and VAMP8 can be found to be actively expressed in vivo in the cortex, hippocampus and striatal astrocytes, based on RNA sequencing [53].

For t-SNARE proteins, astrocytes were shown to express syntaxin1; however, the results of various studies have been mixed. Syntaxin1 has been demonstrated in cultured astrocytes [45,66], albeit at a lower level than in isolated synaptosomal membranes [118]. Additionally, one group failed to find syntaxin1 in cultured astrocytes [119], while another was able to identify it in astrocytes in situ [120]. Syntaxin4, however, seems to have a much higher expression level in astrocytes than syntaxin1, and it was shown to be expressed in culture [66], in situ [121] and ex vivo from freshly isolated astrocytes, based on RNA sequencing [53]. With regard to the second t-SNARE, it seems that astrocytes express SNAP-23 rather than SNAP-25. The latter failed to be found even in cultured astrocytes $[45,66,118,119,122,123]$. SNAP-23 was, however, identified in astrocytes in vitro $[27,29,43,45,46,48,66,122,123]$ and in fixed tissue in vivo $[43,120]$, although one recent study has found its expression to be insignificant, based on RNA sequencing, while showing SNAP-25 expression [53]. Therefore, the expression profile of SNARE proteins in astrocytes seems to follow other non-neuronal cells, where the SNARE complex consists mostly of SNAP-23, syntaxin 4 and VAMP2 (synaptobrevin 2) or VAMP3 (cellubrevin) [124-126].

As mentioned above, the SNARE complex requires SM proteins for its formation, in particular Munc-18 is a prominent and well-studied example. It was shown to be significant for vesicle docking in chromaffin cells where Munc18-1 knockout reduces fraction of docked vesicles from 30\% to 5\% [21,127]. Moreover, Munc18-1 binding to assembling SNARE complexes is essential for synaptic vesicle fusion, and in every SNARE-dependent fusion reaction studied, an SM protein participated and was essential for that fusion reaction [98]. Munc18-1 and Munc18-3 have been found in cultured and freshly isolated astrocytes $[46,66,128]$, while RNA sequencing from freshly isolated astrocytes has shown that they express Munc18-3 rather than Munc18-1, which is expressed in the neurons [52]. A similar result has recently been found in another study using RNA sequencing, where Munc18-1 expression was found in astrocytes at a low level; however, Munc18-3 and Munc18-4 were enriched in the astrocytes [53].

Other components of the exocytosis machinery in astrocytes have not been intensively studied. Notable exceptions are the Rab proteins-small GTPases that are localised on synaptic vesicles and are important for their docking. Cultured astrocytes were shown to express Rab3 [100,101,129,130], which is usually associated with SMLVs or DCVs. A recent study in cultured astrocytes has shown that disruption of Rab3 function by mutated Hunt- 
ingtin blocks the docking of DCVs and ultimately decreases BDNF and ATP release [74]. Expression of Rab7, which is associated with late endosomes/lysosomes, was also reported in astrocytes in vitro $[29,35,91,131]$. Additionally, Rab10 and Rab35 have also been shown to be associated with lysosomes in cultured astrocytes [131]. Thanks to access to a database (http:/ / astrocyternaseq.org/ accessed on 1 January 2021) of sequenced astrocytic RNAs from different brain structures [53], we were able to confirm the expression of Rab3a, Rab7 and Rab35 in freshly isolated astrocytes. All these proteins are expressed at a significantly different level from the expression threshold set as fragments per kilobase per million $($ FPKM) $>10$ (see [53]).

\section{Spatial Organisation of Exocytosis}

Ultrafast neurotransmitter release, which occurs in neurons in response to an action potential, can only be achieved by bringing $\mathrm{Ca}^{2+}$ channels to docked and primed synaptic vesicles at the active zone. Most of the active zones in vertebrates are specialised disclike structures at the plasma membrane with a 0.2-0.5 $\mu \mathrm{m}$ diameter. Active zones are surrounded by a perisynaptic zone containing transsynaptic cell adhesion molecules and receptors regulating neurotransmitter release, which is the site of synaptic vesicle endocytosis [132]. The core of the active zone is formed mainly by the members of six evolutionarily conserved proteins: Rab3-interacting molecules (RIM), RIM-binding proteins (RIM-BP), Munc13 (no relation to Munc18), $\alpha$-liprin and ELKS protein, as well as piccolo/bassoon. RIM, RIM-BP and Munc13, are multidomain proteins, whereas $\alpha$-liprin and ELKS exhibit a simpler structure. Active zone proteins form a single large protein complex that docks and primes synaptic vesicles, recruits $\mathrm{Ca}^{2+}$ channels to the docked and primed vesicles, tethers the vesicles and $\mathrm{Ca}^{2+}$ channels to synaptic cell adhesion molecules, and mediates synaptic plasticity. Astrocytes do not have an active zone that could be observed under an electron microscope; however, the fact that there have been observations of small groups of SMLVs in astrocytes (see above) $[25,38,39]$ suggest the possibility of its existence. To our best knowledge, components of the active zone have not been intensively studied, except for Munc13, which is a priming factor catalysing the conformational switch of syntaxin1 from closed to open, promoting SNARE complex assembly. Mungenast [133] found the expression of Munc13-1 in cultured astrocytes by RT-PCR, immunostaining and Western blotting, and showed that siRNA downregulation of Munc13-1 inhibits astrocytic ATP release, induced by diacylglycerol (DAG). In another study based on RNA sequencing from freshly isolated astrocytes, Munc13-2 and -3 were enriched in the astrocytes, while Munc13-1 was expressed mainly by neurons [52,134]. Similar results can be found in RNA sequencing data from freshly isolated astrocytes; however, only Munc13-3 has shown a significant level of expression in these cells in the striatum [53]. Results showing the expression and function of Munc13 in regulated exocytosis in the astrocytes are very limited, and the involvement of other active zone components in vesicular release could provide more insights into explaining the process. It can be theorised, however, that the spatial organisation of exocytosis in astrocytes might be completely different from that present at a presynaptic site in neurons. For example, a recent report by Buscemi and co-workers showed that mGlu5 interacts with Homer1b/c in astrocytes and that this interaction is crucial for the their glutamate release [135]. The interaction between Homer and mGluR5 in astrocytes has been previously suggested but not shown directly [136]. Homer1 is, however, a neuronal postsynaptic marker (for a review, see [137]) and its role in astrocytes is quite novel. Nevertheless, in line with these observations, neurons may also have "noncanonical" exocytosis machinery, which has been reported, for example, in dendrites [138]. Interestingly, the composition of the SNARE complex, which was proposed to regulate exocytosis from neuronal dendrites, is very similar to that proposed in astrocytes and consists of SNAP-23, syntaxin 4 and VAMP2 or VAMP3 [138]. 


\section{The $\mathrm{Ca}^{2+}$ Sensor for Regulated Exocytosis in Astrocytes}

Under physiological circumstances, primed vesicles are stimulated to exocytosis by $\mathrm{Ca}^{2+}$; therefore, to trigger the final stage of the fusion reaction, $\mathrm{a} \mathrm{Ca}^{2+}$ sensor is required at the site of exocytosis. Since the discovery of synaptotagmin1 (Syt1) [139], it has been proposed to be the $\mathrm{Ca}^{2+}$ sensor for regulated exocytosis. Syts are evolutionarily conserved proteins containing a short amino-terminal sequence directed toward the vesicle lumen, followed by a transmembrane region, a central linker sequence of variable length, and two carboxy-terminal C2 domains that bind $\mathrm{Ca}^{2+}$. $[98,140]$. C2 domains were initially defined in protein-kinase $C$ isozymes and were later shown to constitute autonomously folding $\mathrm{Ca}^{2+}$ / phospholipid-binding domains. In addition, $\mathrm{C} 2$ domains constitute protein interaction domains and, in the case of Syt1, bind to syntaxin-1 and to SNARE complexes. There are 16 Syts expressed in the brain and eight of them bind $\mathrm{Ca}^{2+}$ : Syt1, Syt2, Syt3, Syt5, Syt6, Syt7, Syt9 and Syt10 [140]. Out of those, Syt1, Syt2 and Syt9 are responsible for triggering fast fusion of the synaptic vesicles; however, astrocytes do not seem to express any of them $[52,53,123,141,142]$. Strikingly, for many other forms of regulated, $\mathrm{Ca}^{2+}$-triggered exocytosis, Syt1, Syt2 and Syt 9 are involved in chromaffin cells, neuropeptide secretion in neurons or mast cell degranulation. However, Syt7 has also been shown to be involved in triggering exocytosis in chromaffin cells [143], pancreatic insulin- and glucagon-secreting cells [144,145], or exocytosis of lysosomes in fibroblasts [146]. In neurons, Syt7 was also shown to be important for $\mathrm{Ca}^{2+}$-triggered asynchronous release [147]. For astrocytes, however, results showing Syt7 expression are quite ambiguous. Studies in cultured astrocytes did not detect Syt7 $[142,148]$ or even showed that overexpression of Syt7 inhibited lysosomal exocytosis [148]. However, Mittelsteadt and colleagues [141] showed, using single cell RT-PCR, that patch-clamped hippocampal astrocytes in the CA1 stratum radiatum express Syt7 (in seven out of nine cells). However, cultured astrocytes express Syt4 and Syt11 $[29,65,123,142,148-150]$. Syt4 expression was also found in freshly isolated astrocytes by RT-PCR [142]; similarly, Syt11 was found by RNA sequencing [52,53] and RT-PCR [141]. Zhang and co-workers also confirmed the expression of Syt4 in situ by confocal and electron microscopy. Even though Syt4 and Syt11 do not bind $\mathrm{Ca}^{2+}[151]$, Zhang and co-workers have shown that it regulates astrocytic $\mathrm{Ca}^{2+}$-dependent glutamate release in cultured astrocytes [142]. Similarly, Syt11 was shown to regulate $\mathrm{Ca}^{2+}$-dependent lysosome exocytosis in injured astrocytes [148]. It should be mentioned that there is a whole set of studies showing that astrocytes do not release neurotransmitters in response to $\mathrm{Ca}^{2+}$ elevation, arguing against the existence of $\mathrm{Ca}^{2+}$-dependent exocytosis in astrocytes (for in depth reviews, see $[7,19,20,115,152]$ ). Clearly, the involvement of synaptotagmins in regulated exocytosis in astrocytes needs further studies and clarification, especially in more intact preparations like brain slices or in vivo.

Synaptotagmins, however, do not act alone in triggering fusion but require complexin as a cofactor [140]. Complexin was discovered by virtue of its tight binding to SNARE complexes. It functions as a priming factor for SNARE complexes, as well as an activator of these complexes, preparing them for subsequent synaptotagmin action, and also as a clamp of spontaneous release, preventing unregulated fusion [98]. Complexin's expression in astrocytes has been studied mainly in vitro, where cultured astrocytes have been shown to express complexin 2, while complexin 1 was expressed in the neurons $[46,153,154]$. Recently, complexin 2 expression was confirmed by RNA sequencing data [53], while complexin 1 was also expressed at a significant level, albeit much lower than the general tissue level, and only in cortical astrocytes.

It should also be noted that $\mathrm{Ca}^{2+}$ is not the only signal that can trigger vesicle secretion, as many cells show GTP-dependent DCV secretion. Non-hydrolysable GTP was shown to trigger secretion in a $\mathrm{Ca}^{2+}$-independent manner in chromaffin cells [155], mast cells [156] and pancreatic $\beta$ cells [157]. Even though GTP-dependent exocytosis differs from $\mathrm{Ca}^{2+}$ dependent exocytosis in terms of the signal sensor for triggering, the final fusion steps are still dependent on the SNARE proteins [21]. The major sensors for GTP in GTP-dependent exocytosis are considered to be Ral proteins (RalA and RalB) and GTPases [158]. Ral 
proteins interact with the exocyst protein complex, which is an octameric protein complex containing, among other proteins, Sec5, which is bound by Ral in a GTP-dependent manner [21,159]. It is believed that the exocyst complex tethers secretory vesicles to the plasma membrane, where fusion occurs in a SNARE-dependent manner [159]. For example, live-cell imaging of Sec8 (another member of the exocyst complex) showed that it is transported to a cellular membrane where it remains for seconds until fusion occurs [160], which is in line with the slow kinetics of astrocytic release after stimulus [161]. Additionally, members of the exocyst complex can interact with Rab proteins or v-SNARE [162], directly with plasma membrane via phosphatidylinositol 4,5-bisphosphate (PI $(4,5) \mathrm{P} 2)[163]$, and with a Sec1/Munc18 (SM) protein family member, Sec1 [164]. Interestingly, when we searched for expression of RalA, RalB and Sec5 (encoded in mice by Ral1a, Ral1b and Exoc2, respectively) in a database of sequenced astrocytic RNAs (http:/ / astrocyternaseq.org/ accessed on 1 January 2021), we found that all these proteins are expressed at a significantly different level from the expression threshold set as fragments per kilobase per million $($ FPKM $)>10$ [53]. However, to our knowledge, so far, there are no experimental data exploring the exocyst complex in astrocytes, as it has mostly been studied in yeast. Given the lack of $\mathrm{Ca}^{2+}$-binding synaptotagmins in astrocytes and their slow exocytosis $[37,161]$, GTP-dependent exocytosis could be an interesting alternative hypothesis.

\section{Exocytosis in Pathological Conditions}

In nearly all brain pathologies, such as traumatic brain injury, stroke, ischemia, infectious disease, neuroinflammatory and neurodegenerative disease, epilepsy, brain tumours, schizophrenia, migraine or depression, there is clearly a presence of "reactive astrogliosis" $[165,166]$. This term is a result of a consensus statement [167] recently proposed to describe the process in which, in response to pathology, astrocytes engage in molecularly defined programs involving changes in transcriptional regulation, biochemical, morphological, metabolic and physiological remodelling, which result in a loss of or increase in homeostatic functions and/or the gain of completely new function(s).

Accumulating evidence suggests that in pathological conditions, microglia are activated first and, through the release of ATP and inflammatory mediators (mainly interleukin$1 \alpha$ (IL-1 $\alpha$ ), tumour necrosis factor (TNF) and complement component 1 , subcomponent $\mathrm{q}$ (C1q)), subsequently trigger astrocytic activation $[168,169]$. Activated astrocytes, in turn, increase their production and secretion of chemotactic cytokine stromal cell-derived factor$1 \alpha($ SDF- $1 \alpha)[170,171]$, the proinflammatory cytokine TNF and the inflammatory mediator prostaglandin E2 (PGE2) [105,172], IL-1 $\alpha$, IL-6, interferon- $\gamma$ (IFN- $\gamma$ ) [173] and many others [174]. As mentioned above, some groups have argued that astrocytes are capable of $\mathrm{Ca}^{2+}$-regulated exocytosis only after activation by microglia (see, for example, [115,175]). In support of this view, a previous report by Pascual and co-workers [176] showed that activation of the microglia by lipopolysaccharide (LPS) induced a rapid (within minutes) and transient (several minutes long) increase in the frequency of excitatory synaptic currents in acute hippocampal slices. The proposed mechanism involved the activation of metabotropic P2Y1 receptors (P2Y1Rs) on astrocytes by the release of ATP from the microglia, thus triggering glutamate release from astrocytes and finally modulating synaptic mGluRs. Similarly, it was shown that astrocytes from TNF-deficient or TNF type 1 receptor (TNFR1)-deficient mice displayed altered P2Y1R-dependent $\mathrm{Ca}^{2+}$ signalling and decreased glutamate release [44,177]. Interestingly, a recent study [178] has shown that the presence of microglia downregulates the expression of VAMP2 in astrocytes, which slows down the vesicular release by astrocytes. This favours the longer release of transmitters in opposition to a rapid release and exhaustion of the vesicular pool in the absence of microglial factors. Additionally, the authors showed that the gliotransmission triggered by the P2Y1 agonist is impaired in slices from transgenic mice devoid of microglia [178].

SDF-1 $\alpha$, TNF or PGE2 by themselves are also sufficient to induce glutamate release from astrocytes, albeit still in a $\mathrm{Ca}^{2+}$-dependent manner. They act through activation of their respective receptors-CXCR4 and-, TNFR (both $\mathrm{G}_{\mathrm{i} / \mathrm{o}}$-associated GPCRs)—or prostaglandin 
E (EP) receptors ( $\mathrm{G}_{\mathrm{i}} / \mathrm{G}_{\mathrm{s}}$-associated GPCRs) $[104,105,175,179-181]$. The $\mathrm{Ca}^{2+}$-dependence of the exocytosis of glutamate after activation of these receptors is based on an observation that the response is blocked by intracellular $\mathrm{Ca}^{2+}$ chelators or inhibitors of exocytosis [105].

In physiological conditions, astrocytes maintain constant levels of blood and brain $\mathrm{PCO}_{2} / \mathrm{pH}$ and they respond to physiological decreases in $\mathrm{pH}$ with vigorous elevations in intracellular $\mathrm{Ca}^{2+}$ and regulate the exocytosis of ATP [182]. However, in pathological conditions of hypoxia, they can react to a decrease in $\mathrm{PO} 2 \mathrm{by} \mathrm{Ca}^{2+}$ signalling, accompanied by increases in mitochondrial reactive oxygen species (ROS) production and ATP exocytosis $[183,184]$. In the context of hypoxia, a recent study by Byts and co-workers [185] has shown that transmembrane prolyl 4-hydroxylase (P4H-TM), which is located in the ER and has a $\mathrm{Ca}^{2+}$-sensing EF-domain, controls ATP-induced $\mathrm{Ca}^{2+}$ signalling and gliotransmission. This effect is mediated by hypoxia-inducible factor 1 (HIF1), which is a heterodimeric transcription factor. In normoxia, prolyl 4-hydroxylase $(\mathrm{P} 4 \mathrm{H})$ hydroxylates two prolyl residues located on HIF's $\alpha$ subunit. This hydroxylation leads to von Hippel-Lindau (VHL)-targeted degradation of HIFa, which suppresses the transcription of hypoxia-responsive genes. However, in hypoxia, $\mathrm{P} 4 \mathrm{H}$ is inactive, which leads to stabilisation, accumulation and activation of HIF and induction of hypoxia-responsive genes. One study [185] showed that P4H-TM knockout animals had a changed expression of several genes related to $\mathrm{Ca}^{2+}$ signalling and vesicular transport/docking pathways, thus influencing receptor-operated calcium entry (ROCE) and store-operated calcium entry (SOCE), as well as calcium re-uptake by mitochondria. Moreover, in an in vitro model of cerebral ischemia, oxygen-glucose deprivation (OGD), there was a biphasic increase in $\mathrm{Ca}^{2+}$ signalling in astrocytes as well as neurons and a subsequent accumulation of pro-inflammatory factors, such as IL- $1 \mathrm{~b}$ and TNF $\alpha$, leading to hyperexcitation of the neurons and their death after reoxygenation [186]. Interestingly, pretreatment of cell cultures with the selective $\alpha 2$-adrenergic receptor agonists guanfacine and UK-14,304 showed a neuroprotective effect through $\mathrm{Ca}^{2+}$-regulated exocytosis of ATP [186].

Reactive astrocytes have been also shown to release complement system proteins [187]. The complement system represents one of the most basic immune cascades. The complement proteins $\mathrm{C} 3 \mathrm{a}, \mathrm{C} 1 \mathrm{q}$ and $\mathrm{C} 5$ are present in the brain, where they regulate neurogenesis, neuronal survival and synaptic elimination $[188,189]$. It has been shown that NF- $\mathrm{KB}$ signalling promotes the secretion of C3a. In Alzheimer's disease, exposure to amyloid $\beta$ strongly activates astroglial NF- $\mathrm{KB}$, which increases the astroglial $\mathrm{C} 3 \mathrm{a}$ release that, in turn, contributes to neurodegeneration [187].

Finally, the activation of astrocytes is often associated with their morphological and biochemical remodelling. The reactivity is manifested by an increased expression of intermediate filaments (most notably GFAP and vimentin). It has been suggested that such an upregulation of intermediate filaments allows faster and therefore more efficient delivery of major histocompatibility complex (MHC) Class II molecules to the cell surface. Exposure of astrocytes to INF- $\gamma$ induced MHC Class II expression in late endosomes/lysosomes $[92,96]$.

\section{Conclusions}

Astrocytes are receiving increasing attention as their complex role in the central nervous system becomes more prominent and accepted. In this review, we presented only a fraction of the studies which not only show that astrocytes have various types of secretory vesicles but also that they express a complex molecular machinery associated with those vesicles which is sufficient for their regulated exocytosis. For other excellent in-depth reviews, please see $[36,134,161]$. Even though some of the components of this release machinery, such as SNARE or synaptotagmins, have been intensively studied for over two decades, others have remained mostly undescribed. These include potential scaffolding proteins or components of the active zone, which can direct exocytosis to the most crucial places for astrocyte-neuron communication, but also alternative to $\mathrm{Ca}^{2+}$ mechanisms of triggering exocytosis. Moreover, much attention needs to be given to designing new experiments to bring them to the more physiology-relevant environment 
of neural tissue. New techniques of astrocyte culturing also give hope for creating new study models which will resemble astrocytes in the brain. Regardless of the discussion on $\mathrm{Ca}^{2+}$ sources for triggering exocytosis and gaps in our knowledge about the elements of the exocytotic molecular machinery, astrocytes have proven to be an important component of neuronal networks.

Author Contributions: Conceptualisation, P.M.; investigation, P.M. and A.M.; writing-original draft preparation, P.M., A.M.; writing-review and editing, P.M.; funding acquisition, P.M. All authors have read and agreed to the published version of the manuscript.

Funding: This research was funded by National Science Centre, Poland, grant number 2017/26/D/ NZ3/01017.

Institutional Review Board Statement: Not applicable.

Informed Consent Statement: Not applicable.

Data Availability Statement: Not applicable.

Acknowledgments: We would like to thank Katarzyna Kuter and Agnieszka Jurga for giving us the opportunity to participate in the Special Issue: "Astroglia in Physiology, Pathology and Therapy", and Leszek Kaczmarek for all the support.

Conflicts of Interest: The authors declare no conflict of interest.

\section{References}

1. Oberheim, N.A.; Takano, T.; Han, X.; He, W.; Lin, J.H.C.; Wang, F.; Xu, Q.; Wyatt, J.D.; Pilcher, W.; Ojemann, J.; et al. Uniquely Hominid Features of Adult Human Astrocytes. J. Neurosci. 2009, 29, 3276-3287. [CrossRef] [PubMed]

2. Giaume, C.; Naus, C.C. Connexins, gap junctions, and glia. Wiley Interdiscip. Rev. Membr. Transp. Signal. 2013, 2, 133-142. [CrossRef]

3. Edallérac, G.; Echever, O.; Erouach, N. How do astrocytes shape synaptic transmission? Insights from electrophysiology. Front. Cell. Neurosci. 2013, 7, 159. [CrossRef]

4. Cornell-Bell, A.H.; Finkbeiner, S.M.; Cooper, M.S.; Smith, S.J. Glutamate induces calcium waves in cultured astrocytes: Long-range glial signaling. Science 1990, 247, 470-473. [CrossRef]

5. Agulhon, C.; Petravicz, J.; McMullen, A.B.; Sweger, E.J.; Minton, S.K.; Taves, S.; Casper, K.B.; Fiacco, T.A.; McCarthy, K.D. What Is the Role of Astrocyte Calcium in Neurophysiology? Neuron 2008, 59, 932-946. [CrossRef]

6. Araque, A.; Carmignoto, G.; Haydon, P.G.; Oliet, S.H.; Robitaille, R.; Volterra, A. Gliotransmitters Travel in Time and Space. Neuron 2014, 81, 728-739. [CrossRef]

7. Bazargani, N.; Attwell, D. Astrocyte calcium signaling: The third wave. Nat. Neurosci. 2016, 19, 182-189. [CrossRef]

8. Bekar, L.K.; He, W.; Nedergaard, M. Locus Coeruleus $\alpha$-Adrenergic-Mediated Activation of Cortical Astrocytes In Vivo. Cereb. Cortex 2008, 18, 2789-2795. [CrossRef]

9. Hirase, H.; Qian, L.; Barthó, P.; Buzsaki, G. Calcium Dynamics of Cortical Astrocytic Networks In Vivo. PLoS Biol. 2004,2 , e96. [CrossRef]

10. Nedergaard, M. Direct signaling from astrocytes to neurons in cultures of mammalian brain cells. Science 1994, 263, 1768-1771. [CrossRef]

11. Parpura, V.; Basarsky, T.A.; Liu, F.; Jeftinija, K.; Jeftinija, S.; Haydon, P.G. Glutamate-mediated astrocyte-neuron signalling. Nat. Cell Biol. 1994, 369, 744-747. [CrossRef]

12. Perea, G.; Navarrete, M.; Araque, A. Tripartite synapses: Astrocytes process and control synaptic information. Trends Neurosci. 2009, 32, 421-431. [CrossRef]

13. Volterra, A.; Liaudet, N.; Savtchouk, I. Astrocyte $\mathrm{Ca}^{2+}$ signalling: An unexpected complexity. Nat. Rev. Neurosci. 2014, 15, 327-335. [CrossRef]

14. Hamilton-Whitaker, N.; Attwell, D. Do astrocytes really exocytose neurotransmitters? Nat. Rev. Neurosci. 2010, 11, 227-238. [CrossRef] [PubMed]

15. Angulo, M.C.; Kozlov, A.S.; Charpak, S.; Audinat, E. Glutamate Released from Glial Cells Synchronizes Neuronal Activity in the Hippocampus. J. Neurosci. 2004, 24, 6920-6927. [CrossRef]

16. Henneberger, C.; Papouin, T.; Oliet, S.H.R.; Rusakov, D.A. Long-term potentiation depends on release of d-serine from astrocytes. Nature 2010, 463, 232-236. [CrossRef] [PubMed]

17. Pascual, O.; Casper, K.B.; Kubera, C.; Zhang, J.; Revilla-Sanchez, R.; Sul, J.-Y.; Takano, H.; Moss, S.J.; McCarthy, K.; Haydon, P.G. Astrocytic Purinergic Signaling Coordinates Synaptic Networks. Science 2005, 310, 113-116. [CrossRef] [PubMed]

18. Serrano, A.; Haddjeri, N.; Lacaille, J.-C.; Robitaille, R. GABAergic Network Activation of Glial Cells Underlies Hippocampal Heterosynaptic Depression. J. Neurosci. 2006, 26, 5370-5382. [CrossRef] 
19. Fiacco, T.A.; McCarthy, K.D. Multiple Lines of Evidence Indicate That Gliotransmission Does Not Occur under Physiological Conditions. J. Neurosci. 2018, 38, 3-13. [CrossRef]

20. Savtchouk, I.; Volterra, A. Gliotransmission: Beyond Black-and-White. J. Neurosci. 2018, 38, 14-25. [CrossRef] [PubMed]

21. Sugita, S. Mechanisms of exocytosis. Acta Physiol. 2007, 192, 185-193. [CrossRef]

22. Thorn, P.; Zorec, R.; Rettig, J.; Keating, D.J. Exocytosis in non-neuronal cells. J. Neurochem. 2016, 137, 849-859. [CrossRef]

23. Südhof, T.C.; Rizo, J. Synaptic Vesicle Exocytosis. Cold Spring Harb. Perspect. Biol. 2011, 3, a005637. [CrossRef]

24. Chanaday, N.L.; Cousin, M.A.; Milosevic, I.; Watanabe, S.; Morgan, J.R. The Synaptic Vesicle Cycle Revisited: New Insights into the Modes and Mechanisms. J. Neurosci. 2019, 39, 8209-8216. [CrossRef] [PubMed]

25. Bezzi, P.; Gundersen, V.; Galbete, J.L.; Seifert, G.; Steinhäuser, C.; Pilati, E.; Volterra, A. Astrocytes contain a vesicular compartment that is competent for regulated exocytosis of glutamate. Nat. Neurosci. 2004, 7, 613-620. [CrossRef]

26. Jourdain, P.; Bergersen, L.H.; Bhaukaurally, K.; Bezzi, P.; Santello, M.; Domercq, M.; Matute, C.; Tonello, F.; Gundersen, V.; Volterra, A. Glutamate exocytosis from astrocytes controls synaptic strength. Nat. Neurosci. 2007, 10, 331-339. [CrossRef]

27. Martineau, M.; Shi, T.; Puyal, J.; Knolhoff, A.; Dulong, J.; Gasnier, B.; Klingauf, J.; Sweedler, J.V.; Jahn, R.; Mothet, J.-P. Storage and uptake of d-serine into astrocytic synaptic-like vesicles specify gliotransmission. J. Neurosci. 2013, 33, 3413-3423. [CrossRef] [PubMed]

28. Bergersen, L.; Gundersen, V. Morphological evidence for vesicular glutamate release from astrocytes. Neuroscience 2009, 158, 260-265. [CrossRef] [PubMed]

29. Crippa, D.; Schenk, U.; Francolini, M.; Rosa, P.; Verderio, C.; Zonta, M.; Pozzan, T.; Matteoli, M.; Carmignoto, G. Synaptobrevin2expressing vesicles in rat astrocytes: Insights into molecular characterization, dynamics and exocytosis. J. Physiol. 2006, 570, 567-582. [CrossRef]

30. Calegari, F.; Coco, S.; Taverna, E.; Bassetti, M.; Verderio, C.; Corradi, N.; Matteoli, M.; Rosa, P. A Regulated Secretory Pathway in Cultured Hippocampal Astrocytes. J. Biol. Chem. 1999, 274, 22539-22547. [CrossRef]

31. Prada, I.; Marchaland, J.; Podini, P.; Magrassi, L.; D'Alessandro, R.; Bezzi, P.; Meldolesi, J. REST/NRSF governs the expression of dense-core vesicle gliosecretion in astrocytes. J. Cell Biol. 2011, 193, 537-549. [CrossRef]

32. Hur, Y.S.; Kim, K.D.; Paek, S.H.; Yoo, S.H. Evidence for the Existence of Secretory Granule (Dense-Core Vesicle)-Based Inositol 1,4,5-Trisphosphate-Dependent $\mathrm{Ca}^{2+}$ Signaling System in Astrocytes. PLoS ONE 2010, 5, e11973. [CrossRef] [PubMed]

33. Liu, T.; Sun, L.; Xiong, Y.; Shang, S.; Guo, N.; Teng, S.; Wang, Y.; Liu, B.; Wang, C.; Wang, L.; et al. Calcium Triggers Exocytosis from Two Types of Organelles in a Single Astrocyte. J. Neurosci. 2011, 31, 10593-10601. [CrossRef]

34. Zhang, Z.; Chen, G.; Zhou, W.; Song, A.; Xu, T.; Luo, Q.; Wang, W.; Gu, X.-S.; Duan, S. Regulated ATP release from astrocytes through lysosome exocytosis. Nat. Cell Biol. 2007, 9, 945-953. [CrossRef]

35. Li, D.; Ropert, N.; Koulakoff, A.; Giaume, C.; Oheim, M. Lysosomes Are the Major Vesicular Compartment Undergoing $\mathrm{Ca}^{2+}$-Regulated Exocytosis from Cortical Astrocytes. J. Neurosci. 2008, 28, 7648-7658. [CrossRef] [PubMed]

36. Vardjan, N.; Parpura, V.; Verkhratsky, A.; Zorec, R. Gliocrine System: Astroglia as Secretory Cells of the CNS. In Advances in Experimental Medicine and Biology; Springer Science and Business Media LLC: Berlin, Germany, 2019; Volume 1175, pp. 93-115.

37. Verkhratsky, A.; Matteoli, M.; Parpura, V.; Mothet, J.; Zorec, R. Astrocytes as secretory cells of the central nervous system: Idiosyncrasies of vesicular secretion. EMBO J. 2016, 35, 239-257. [CrossRef] [PubMed]

38. Bergersen, L.; Morland, C.; Ormel, L.; Rinholm, J.; Larsson, M.; Wold, J.; Røe, Å.T.; Stranna, A.; Santello, M.; Bouvier, D.; et al. Immunogold Detection of L-glutamate and D-serine in Small Synaptic-Like Microvesicles in Adult Hippocampal Astrocytes. Cereb. Cortex 2012, 22, 1690-1697. [CrossRef]

39. Ormel, L.; Stensrud, M.J.; Bergersen, L.H.; Gundersen, V. VGLUT1 is localized in astrocytic processes in several brain regions. Glia 2012, 60, 229-238. [CrossRef] [PubMed]

40. Patrushev, I.; Gavrilov, N.; Turlapov, V.; Semyanov, A. Subcellular location of astrocytic calcium stores favors extrasynaptic neuron-astrocyte communication. Cell Calcium 2013, 54, 343-349. [CrossRef]

41. Stenovec, M.; Kreft, M.; Grilc, S.; Potokar, M.; Kreft, M.E.; Pangršič, T.; Zorec, R. Ca ${ }^{2+}$-dependent mobility of vesicles capturing anti-VGLUT1 antibodies. Exp. Cell Res. 2007, 313, 3809-3818. [CrossRef]

42. Hiasa, M.; Miyaji, T.; Haruna, Y.; Takeuchi, T.; Harada, Y.; Moriyama, S.; Yamamoto, A.; Omote, H.; Moriyama, Y. Identification of a mammalian vesicular polyamine transporter. Sci. Rep. 2015, 4, 6836. [CrossRef] [PubMed]

43. Wilhelm, A.; Volknandt, W.; Langer, D.; Nolte, C.; Kettenmann, H.; Zimmermann, H. Localization of SNARE proteins and secretory organelle proteins in astrocytes in vitro and in situ. Neurosci. Res. 2004, 48, 249-257. [CrossRef]

44. Domercq, M.; Brambilla, L.; Pilati, E.; Marchaland, J.; Volterra, A.; Bezzi, P. P2Y1 Receptor-evoked Glutamate Exocytosis from Astrocytes. J. Biol. Chem. 2006, 281, 30684-30696. [CrossRef]

45. Montana, V.; Ni, Y.; Sunjara, V.; Hua, X.; Parpura, V. Vesicular Glutamate Transporter-Dependent Glutamate Release from Astrocytes. J. Neurosci. 2004, 24, 2633-2642. [CrossRef]

46. Zhang, Q.; Pangršič, T.; Kreft, M.; Kržan, M.; Li, N.; Sul, J.-Y.; Halassa, M.; Van Bockstaele, E.; Zorec, R.; Haydon, P.G. Fusionrelated Release of Glutamate from Astrocytes. J. Biol. Chem. 2004, 279, 12724-12733. [CrossRef] [PubMed]

47. Kasymov, V.; Larina, O.; Castaldo, C.; Marina, N.; Patrushev, M.; Kasparov, S.; Gourine, A.V. Differential Sensitivity of Brainstem versus Cortical Astrocytes to Changes in pH Reveals Functional Regional Specialization of Astroglia. J. Neurosci. 2013, 33, 435-441. [CrossRef] 
48. Höltje, M.; Hofmann, F.; Lux, R.; Veh, R.W.; Just, I.; Ahnert-Hilger, G. Glutamate Uptake and Release by Astrocytes Are Enhanced by Clostridium botulinum C3 Protein. J. Biol. Chem. 2008, 283, 9289-9299. [CrossRef] [PubMed]

49. Bowser, D.; Khakh, B.S. Two forms of single-vesicle astrocyte exocytosis imaged with total internal reflection fluorescence microscopy. Proc. Natl. Acad. Sci. USA 2007, 104, 4212-4217. [CrossRef] [PubMed]

50. Fremeau, R.T.; Burman, J.; Qureshi, T.; Tran, C.H.; Proctor, J.; Johnson, J.; Zhang, H.; Sulzer, D.; Copenhagen, D.R.; Storm-Mathisen, J.; et al. The identification of vesicular glutamate transporter 3 suggests novel modes of signaling by glutamate. Proc. Natl. Acad. Sci. USA 2002, 99, 14488-14493. [CrossRef] [PubMed]

51. Ormel, L.; Stensrud, M.J.; Chaudhry, F.A.; Gundersen, V. A distinct set of synaptic-like microvesicles in atroglial cells contain VGLUT3. Glia 2012, 60, 1289-1300. [CrossRef] [PubMed]

52. Zhang, Y.; Chen, K.; Sloan, S.A.; Bennett, M.L.; Scholze, A.R.; O’Keeffe, S.; Phatnani, H.P.; Guarnieri, P.; Caneda, C.; Ruderisch, N.; et al. An RNA-Sequencing Transcriptome and Splicing Database of Glia, Neurons, and Vascular Cells of the Cerebral Cortex. J. Neurosci. 2014, 34, 11929-11947. [CrossRef] [PubMed]

53. Chai, H.; Diaz-Castro, B.; Shigetomi, E.; Monte, E.; Octeau, J.C.; Yu, X.; Cohn, W.; Rajendran, P.S.; Vondriska, T.M.; Whitelegge, J.P.; et al. Neural Circuit-Specialized Astrocytes: Transcriptomic, Proteomic, Morphological, and Functional Evidence. Neuron 2017, 95, 531-549.e9. [CrossRef] [PubMed]

54. Cahoy, J.D.; Emery, B.; Kaushal, A.; Foo, L.C.; Zamanian, J.; Christopherson, K.S.; Xing, Y.; Lubischer, J.; Krieg, P.A.; Krupenko, S.A.; et al. A Transcriptome Database for Astrocytes, Neurons, and Oligodendrocytes: A New Resource for Understanding Brain Development and Function. J. Neurosci. 2008, 28, 264-278. [CrossRef]

55. Li, D.; Hérault, K.; Silm, K.; Evrard, A.; Wojcik, S.; Oheim, M.; Herzog, E.; Ropert, N. Lack of Evidence for Vesicular Glutamate Transporter Expression in Mouse Astrocytes. J. Neurosci. 2013, 33, 4434-4455. [CrossRef]

56. Guček, A.; Vardjan, N.; Zorec, R. Exocytosis in Astrocytes: Transmitter Release and Membrane Signal Regulation. Neurochem. Res. 2012, 37, 2351-2363. [CrossRef]

57. Vardjan, N.; Kreft, M.; Zorec, R. Regulated Exocytosis in Astrocytes is as Slow as the Metabolic Availability of Gliotransmitters: Focus on Glutamate and ATP. Adv. Neurobiol. 2014, 11, 81-101.

58. El Mestikawy, S.; Mackenzie, Å.; Fortin, G.M.; Descarries, L.; Trudeau, L.-E. From glutamate co-release to vesicular synergy: Vesicular glutamate transporters. Nat. Rev. Neurosci. 2011, 12, 204-216. [CrossRef] [PubMed]

59. Martineau, M.; Galli, T.; Baux, G.; Mothet, J.-P. Confocal imaging and tracking of the exocytotic routes for d-serine-mediated gliotransmission. Glia 2008, 56, 1271-1284. [CrossRef] [PubMed]

60. Mothet, J.-P.; Pollegioni, L.; Ouanounou, G.; Martineau, M.; Fossier, P.; Baux, G. Glutamate receptor activation triggers a calciumdependent and SNARE protein-dependent release of the gliotransmitter d-serine. Proc. Natl. Acad. Sci. USA 2005, 102, 5606-5611. [CrossRef] [PubMed]

61. Wolosker, H.; Balu, D.T.; Coyle, J.T. The Rise and Fall of the d -Serine-Mediated Gliotransmission Hypothesis. Trends Neurosci. 2016, 39, 712-721. [CrossRef] [PubMed]

62. Papouin, T.; Henneberger, C.; Rusakov, D.A.; Oliet, S.H. Astroglial versus Neuronal d-Serine: Fact Checking. Trends Neurosci. 2017, 40, 517-520. [CrossRef]

63. Neame, S.; Safory, H.; Radzishevsky, I.; Touitou, A.; Marchesani, F.; Marchetti, M.; Kellner, S.; Berlin, S.; Foltyn, V.N.; Engelender, $\mathrm{S}$; ; et al. The NMDA receptor activation by d-serine and glycine is controlled by an astrocytic Phgdh-dependent serine shuttle. Proc. Natl. Acad. Sci. USA 2019, 116, 20736-20742. [CrossRef] [PubMed]

64. Perez, E.J.; Tapanes, S.A.; Loris, Z.B.; Balu, D.; Sick, T.J.; Coyle, J.T.; Liebl, D.J. Enhanced astrocytic d-serine underlies synaptic damage after traumatic brain injury. J. Clin. Investig. 2017, 127, 3114-3125. [CrossRef] [PubMed]

65. Potokar, M.; Stenovec, M.; Kreft, M.; Kreft, M.E.; Zorec, R. Stimulation inhibits the mobility of recycling peptidergic vesicles in astrocytes. Glia 2007, 56, 135-144. [CrossRef] [PubMed]

66. Paco, S.; Margelí, M.A.; Olkkonen, V.M.; Imai, A.; Blasi, J.; Aguado, F.; Fischer-Colbrie, R. Regulation of exocytotic protein expression and $\mathrm{Ca}^{2+}$-dependent peptide secretion in astrocytes. J. Neurochem. 2009, 110, 143-156. [CrossRef]

67. Fischer-Colbrie, R.; Kirchmair, R.; Schobert, A.; Olenik, C.; Meyer, D.K.; Winkler, H. Secretogranin II Is Synthesized and Secreted in Astrocyte Cultures. J. Neurochem. 1993, 60, 2312-2314. [CrossRef] [PubMed]

68. Paco, S.; Pozas, E.; Aguado, F. Secretogranin III Is an Astrocyte Granin That Is Overexpressed in Reactive Glia. Cereb. Cortex 2009, 20, 1386-1397. [CrossRef]

69. Zhan, X.; Wen, G.; Jiang, E.; Li, F.; Wu, X.; Pang, H. Secretogranin III upregulation is involved in parkinsonian toxin-mediated astroglia activation. J. Toxicol. Sci. 2020, 45, 271-280. [CrossRef]

70. Kreft, M.; Stenovec, M.; Rupnik, M.S.; Grilc, S.; Kržan, M.; Potokar, M.; Pangršič, T.; Haydon, P.G.; Zorec, R. Properties of $\mathrm{Ca}^{2+}$-dependent exocytosis in cultured astrocytes. Glia 2004, 46, 437-445. [CrossRef]

71. Chatterjee, S.; Sikdar, S.K. Corticosterone treatment results in enhanced release of peptidergic vesicles in astrocytes via cytoskeletal rearrangements. Glia 2013, 61, 2050-2062. [CrossRef]

72. Ramamoorthy, P.; Whim, M.D. Trafficking and Fusion of Neuropeptide Y-Containing Dense-Core Granules in Astrocytes. J. Neurosci. 2008, 28, 13815-13827. [CrossRef] [PubMed]

73. Guček, A.; Jorgačevski, J.; Singh, P.; Geisler, C.; Lisjak, M.; Vardjan, N.; Kreft, M.; Egner, A.; Zorec, R. Dominant negative SNARE peptides stabilize the fusion pore in a narrow, release-unproductive state. Cell. Mol. Life Sci. 2016, 73, 3719-3731. [CrossRef] [PubMed] 
74. Hong, Y.; Zhao, T.; Li, X.-J.; Li, S. Mutant Huntingtin Impairs BDNF Release from Astrocytes by Disrupting Conversion of Rab3a-GTP into Rab3a-GDP. J. Neurosci. 2016, 36, 8790-8801. [CrossRef] [PubMed]

75. Coco, S.; Calegari, F.; Pravettoni, E.; Pozzi, D.; Taverna, E.; Rosa, P.; Matteoli, M.; Verderio, C. Storage and Release of ATP from Astrocytes in Culture. J. Biol. Chem. 2003, 278, 1354-1362. [CrossRef]

76. Pangršič, T.; Potokar, M.; Stenovec, M.; Kreft, M.; Fabbretti, E.; Nistri, A.; Pryazhnikov, E.; Khiroug, L.; Giniatullin, R.; Zorec, R. Exocytotic Release of ATP from Cultured Astrocytes. J. Biol. Chem. 2007, 282, 28749-28758. [CrossRef]

77. Potokar, M.; Kreft, M.; Pangršič, T.; Zorec, R. Vesicle mobility studied in cultured astrocytes. Biochem. Biophys. Res. Commun. 2005, 329, 678-683. [CrossRef]

78. Potokar, M.; Vardjan, N.; Stenovec, M.; Gabrijel, M.; Trkov, S.; Jorgačevski, J.; Kreft, M.; Zorec, R. Astrocytic Vesicle Mobility in Health and Disease. Int. J. Mol. Sci. 2013, 14, 11238-11258. [CrossRef]

79. Bowser, D.; Khakh, B.S. Vesicular ATP Is the Predominant Cause of Intercellular Calcium Waves in Astrocytes. J. Gen. Physiol. 2007, 129, 485-491. [CrossRef] [PubMed]

80. Hines, D.J.; Haydon, P.G. Astrocytic adenosine: From synapses to psychiatric disorders. Philos. Trans. R. Soc. B Biol. Sci. 2014, 369, 20130594. [CrossRef]

81. Sawada, K.; Echigo, N.; Juge, N.; Miyaji, T.; Otsuka, M.; Omote, H.; Yamamoto, A.; Moriyama, Y. Identification of a vesicular nucleotide transporter. Proc. Natl. Acad. Sci. USA 2008, 105, 5683-5686. [CrossRef]

82. Imura, Y.; Morizawa, Y.; Komatsu, R.; Shibata, K.; Shinozaki, Y.; Kasai, H.; Moriishi, K.; Moriyama, Y.; Koizumi, S. Microglia release ATP by exocytosis. Glia 2013, 61, 1320-1330. [CrossRef]

83. Oya, M.; Kitaguchi, T.; Yanagihara, Y.; Numano, R.; Kakeyama, M.; Ikematsu, K.; Tsuboi, T. Vesicular nucleotide transporter is involved in ATP storage of secretory lysosomes in astrocytes. Biochem. Biophys. Res. Commun. 2013, 438, 145-151. [CrossRef]

84. Angelova, P.R.; Iversen, K.Z.; Teschemacher, A.G.; Kasparov, S.; Gourine, A.V.; Abramov, A.Y. Signal transduction in astrocytes: Localization and release of inorganic polyphosphate. Glia 2018, 66, 2126-2136. [CrossRef]

85. Beckel, J.M.; Gómez, N.M.; Lu, W.; Campagno, K.; Nabet, B.; AlBalawi, F.; Lim, J.C.; Boesze-Battaglia, K.; Mitchell, C.H. Stimulation of TLR3 triggers release of lysosomal ATP in astrocytes and epithelial cells that requires TRPML1 channels. Sci. Rep. 2018, 8, 1-14. [CrossRef]

86. Lalo, U.; Palygin, O.; Rasooli-Nejad, S.; Andrew, J.; Haydon, P.G.; Pankratov, Y. Exocytosis of ATP From Astrocytes Modulates Phasic and Tonic Inhibition in the Neocortex. PLoS Biol. 2014, 12, e1001747. [CrossRef] [PubMed]

87. Kinoshita, M.; Hirayama, Y.; Fujishita, K.; Shibata, K.; Shinozaki, Y.; Shigetomi, E.; Takeda, A.; Le, H.P.N.; Hayashi, H.; Hiasa, M.; et al. Anti-Depressant Fluoxetine Reveals its Therapeutic Effect Via Astrocytes. EBioMedicine 2018, 32, 72-83. [CrossRef]

88. Chen, X.; Wang, L.; Zhou, Y.; Zheng, L.-H.; Zhou, Z. "Kiss-and-Run" Glutamate Secretion in Cultured and Freshly Isolated Rat Hippocampal Astrocytes. J. Neurosci. 2005, 25, 9236-9243. [CrossRef]

89. Jaiswal, J.K.; Fix, M.; Takano, T.; Nedergaard, M.; Simon, S.M. Resolving vesicle fusion from lysis to monitor calcium-triggered lysosomal exocytosis in astrocytes. Proc. Natl. Acad. Sci. USA 2007, 104, 14151-14156. [CrossRef] [PubMed]

90. Li, L.; Lundkvist, A.; Andersson, D.; Wilhelmsson, U.; Nagai, N.; Pardo, A.; Nodin, C.; Ståhlberg, A.; Aprico, K.; Larsson, K.; et al. Protective Role of Reactive Astrocytes in Brain Ischemia. Br. J. Pharmacol. 2007, 28, 468-481. [CrossRef]

91. Verderio, C.; Cagnoli, C.; Bergami, M.; Francolini, M.; Schenk, U.; Colombo, A.; Riganti, L.; Frassoni, C.; Zuccaro, E.; Danglot, L.; et al. TI-VAMP/VAMP7 is the SNARE of secretory lysosomes contributing to ATP secretion from astrocytes. Biol. Cell 2012, 104, 213-228. [CrossRef]

92. Vardjan, N.; Gabrijel, M.; Potokar, M.; Švajger, U.; Kreft, M.; Jeras, M.; de Pablo, Y.; Faiz, M.; Pekny, M.; Zorec, R. IFN- $\gamma$-induced increase in the mobility of MHC class II compartments in astrocytes depends on intermediate filaments. J. Neuroinflam. 2012, 9, 144. [CrossRef] [PubMed]

93. Jaiswal, J.; Andrews, N.; Simon, S.M. Membrane proximal lysosomes are the major vesicles responsible for calcium-dependent exocytosis in nonsecretory cells. J. Cell Biol. 2002, 159, 625-635. [CrossRef]

94. Soerensen, C.; Novak, I. Visualization of ATP Release in Pancreatic Acini in Response to Cholinergic Stimulus. J. Biol. Chem. 2001, 276, 32925-32932. [CrossRef]

95. Li, D.; Herault, K.; Oheim, M.; Ropert, N. FM dyes enter via a store-operated calcium channel and modify calcium signaling of cultured astrocytes. Proc. Natl. Acad. Sci. USA 2009, 106, 21960-21965. [CrossRef] [PubMed]

96. Božić, M.; Verkhratsky, A.; Zorec, R.; Stenovec, M. Exocytosis of large-diameter lysosomes mediates interferon $\gamma$-induced relocation of MHC class II molecules toward the surface of astrocytes. Cell. Mol. Life Sci. 2019, 77, 3245-3264. [CrossRef] [PubMed]

97. Söllner, T.; Bennett, M.K.; Whiteheart, S.; Scheller, R.H.; Rothman, J.E. A protein assembly-disassembly pathway in vitro that may correspond to sequential steps of synaptic vesicle docking, activation, and fusion. Cell 1993, 75, 409-418. [CrossRef]

98. Südhof, T.C. Neurotransmitter release: The last millisecond in the life of a synaptic vesicle. Neuron 2013, 80, 675-690. [CrossRef] [PubMed]

99. Aslamy, A.; Thurmond, D.C. Exocytosis proteins as novel targets for diabetes prevention and/or remediation? Am. J. Physiol. Integr. Comp. Physiol. 2017, 312, R739-R752. [CrossRef]

100. Anlauf, E.; Derouiche, A. Astrocytic exocytosis vesicles and glutamate: A high-resolution immunofluorescence study. Glia 2004, 49, 96-106. [CrossRef]

101. Maienschein, V.; Marxen, M.; Volknandt, W.; Zimmermann, H. A plethora of presynaptic proteins associated with ATP-storing organelles in cultured astrocytes. Glia 1999, 26, 233-244. [CrossRef] 
102. Singh, P.; Jorgačevski, J.; Kreft, M.; Grubišić, V.; Stout, R.; Potokar, M.; Parpura, V.; Zorec, R. Single-vesicle architecture of synaptobrevin2 in astrocytes. Nat. Commun. 2014, 5, 1-12. [CrossRef] [PubMed]

103. Kim, J.-H.; Kim, J.-H.; Cho, Y.-E.; Baek, M.-C.; Jung, J.-Y.; Lee, M.-G.; Jang, I.-S.; Lee, H.-W.; Suk, K. Chronic Sleep DeprivationInduced Proteome Changes in Astrocytes of the Rat Hypothalamus. J. Proteome Res. 2014, 13, 4047-4061. [CrossRef] [PubMed]

104. Bezzi, P.; Carmignoto, P.; Pasti, L.; Vesce, S.; Rossi, D.M.; Rizzini, B.L.; Pozzan, T.; Volterra, A. Prostaglandins stimulate calcium-dependent glutamate release in astrocytes. Nat. Cell Biol. 1998, 391, 281-285. [CrossRef]

105. Bezzi, P.; Domercq, M.; Brambilla, L.; Galli, R.; Schols, D.; De Clercq, E.; Vescovi, A.; Bagetta, G.; Kollias, G.; Meldolesi, J.; et al. CXCR4-activated astrocyte glutamate release via TNF $\alpha$ : Amplification by microglia triggers neurotoxicity. Nat. Neurosci. 2001, 4, 702-710. [CrossRef]

106. Hua, X.; Malarkey, E.B.; Sunjara, V.; Rosenwald, S.E.; Li, W.-H.; Parpura, V. Ca ${ }^{2+}$-dependent glutamate release involves two classes of endoplasmic reticulum $\mathrm{Ca}^{2+}$ stores in astrocytes. J. Neurosci. Res. 2004, 76, 86-97. [CrossRef]

107. Perea, G.; Araque, A. Astrocytes Potentiate Transmitter Release at Single Hippocampal Synapses. Science 2007, 317, 1083-1086. [CrossRef]

108. Halassa, M.M.; Florian, C.; Fellin, T.; Munoz, J.R.; Lee, S.-Y.; Abel, T.; Haydon, P.G.; Frank, M.G. Astrocytic Modulation of Sleep Homeostasis and Cognitive Consequences of Sleep Loss. Neuron 2009, 61, 213-219. [CrossRef]

109. Hines, D.; Haydon, P.G. Inhibition of a SNARE-sensitive pathway in astrocytes attenuates damage following stroke. J. Neurosci. 2013, 33, 4234-4240. [CrossRef] [PubMed]

110. Sultan, S.; Li, L.; Moss, J.; Petrelli, F.; Cassé, F.; Gebara, E.; Lopatar, J.; Pfrieger, F.; Bezzi, P.; Bischofberger, J.; et al. Synaptic Integration of Adult-Born Hippocampal Neurons Is Locally Controlled by Astrocytes. Neuron 2015, 88, 957-972. [CrossRef] [PubMed]

111. Sardinha, V.M.; Guerra-Gomes, S.; Caetano, I.; Tavares, G.; Martins, M.; Reis, J.S.; Correia, J.S.; Teixeira-Castro, A.; Pinto, L.; Sousa, N.; et al. Astrocytic signaling supports hippocampal-prefrontal theta synchronization and cognitive function. Glia 2017, 65, 1944-1960. [CrossRef] [PubMed]

112. Nadjar, A.; Blutstein, T.; Aubert, A.; Laye, S.; Haydon, P.G. Astrocyte-derived adenosine modulates increased sleep pressure during inflammatory response. Glia 2013, 61, 724-731. [CrossRef] [PubMed]

113. Turner, J.R.; Ecke, L.E.; Briand, L.A.; Haydon, P.G.; Blendy, J.A.; Haydon, P. Cocaine-related behaviors in mice with deficient gliotransmission. Psychopharmacology 2013, 226, 167-176. [CrossRef] [PubMed]

114. Fujita, T.; Chen, M.J.; Li, B.; Smith, N.; Peng, W.; Sun, W.; Toner, M.J.; Kress, B.T.; Wang, L.; Benraiss, A.; et al. Neuronal transgene expression in dominant-negative SNARE mice. J. Neurosci. 2014, 34, 16594-16604. [CrossRef]

115. Sloan, S.A.; Barres, B.A. Looks Can Be Deceiving: Reconsidering the Evidence for Gliotransmission. Neuron 2014, 84, 1112-1115. [CrossRef]

116. Petrelli, F.; Bezzi, P. Novel insights into gliotransmitters. Curr. Opin. Pharmacol. 2016, 26, 138-145. [CrossRef]

117. Ślęzak, M.; Grosche, A.; Niemiec, A.; Tanimoto, N.; Pannicke, T.; Münch, T.; Crocker, B.; Isope, P.; Härtig, W.; Beck, S.C.; et al. Relevance of Exocytotic Glutamate Release from Retinal Glia. Neuron 2012, 74, 504-516. [CrossRef]

118. Parpura, V.; Fang, Y.; Basarsky, T.; Jahn, R.; Haydon, P.G. Expression of synaptobrevin II, cellubrevin and syntaxin but not SNAP-25 in cultured astrocytes. FEBS Lett. 1995, 377, 489-492. [CrossRef]

119. Jeftinija, S.D.; Jeftinija, K.V.; Stefanović, G. Cultured astrocytes express proteins involved in vesicular glutamate release. Brain Res. 1997, 750, 41-47. [CrossRef]

120. Schubert, V.; Bouvier, D.; Volterra, A. SNARE protein expression in synaptic terminals and astrocytes in the adult hippocampus: A comparative analysis. Glia 2011, 59, 1472-1488. [CrossRef]

121. Tao-Cheng, J.-H.; Pham, A.; Yang, Y.; Winters, C.; Gallant, P.; Reese, T. Syntaxin 4 is concentrated on plasma membrane of astrocytes. Neuroscience 2015, 286, 264-271. [CrossRef] [PubMed]

122. Hepp, R.; Perraut, M.; Chasserot-Golaz, S.; Galli, T.; Aunis, D.; Langley, K.; Grant, N.J. Cultured glial cells express the SNAP-25 analogue SNAP-23. Glia 1999, 27, 181-187. [CrossRef]

123. Malarkey, E.B.; Parpura, V. Temporal characteristics of vesicular fusion in astrocytes: Examination of synaptobrevin 2-laden vesicles at single vesicle resolution. J. Physiol. 2011, 589, 4271-4300. [CrossRef]

124. Smithers, N.P.; Hodgkinson, C.P.; Cuttle, M.; Sale, G.J. Insulin-triggered repositioning of munc18c on syntaxin-4 in GLUT4 signalling. Biochem. J. 2008, 410, 255-260. [CrossRef]

125. Predescu, S.; Predescu, D.N.; Shimizu, K.; Klein, I.K.; Malik, A.B. Cholesterol-dependent Syntaxin-4 and SNAP-23 Clustering Regulates Caveolar Fusion with the Endothelial Plasma Membrane. J. Biol. Chem. 2005, 280, 37130-37138. [CrossRef] [PubMed]

126. Brandie, F.M.; Aran, V.; Verma, A.; McNew, J.A.; Bryant, N.J.; Gould, G. Negative Regulation of Syntaxin4/SNAP-23/VAMP2Mediated Membrane Fusion by Munc18c In Vitro. PLoS ONE 2008, 3, e4074. [CrossRef] [PubMed]

127. Voets, T.; Toonen, R.F.; Brian, E.C.; de Wit, H.; Moser, T.; Rettig, J.; Südhof, T.C.; Neher, E.; Verhage, M. Munc18-1 Promotes Large Dense-Core Vesicle Docking. Neuron 2001, 31, 581-592. [CrossRef]

128. Oh, E.; Kalwat, M.; Kim, M.-J.; Verhage, M.; Thurmond, D.C. Munc18-1 Regulates First-phase Insulin Release by Promoting Granule Docking to Multiple Syntaxin Isoforms. J. Biol. Chem. 2012, 287, 25821-25833. [CrossRef]

129. Motoike, T.; Sano, K.; Nakamura, H.; Takai, Y. Expression of smg p25A/rab 3A guanine nucleotide dissociation inhibitor (GDI) in neurons and glial cells from rat brain. Neurosci. Lett. 1993, 156, 87-90. [CrossRef] 
130. Madison, D.; Krüger, W.; Kim, T.; Pfeiffer, S. Differential expression of rab3 isoforms in oligodendrocytes and astrocytes. J. Neurosci. Res. 1996, 45, 258-268. [CrossRef]

131. Bonet-Ponce, L.; Beilina, A.; Williamson, C.D.; Lindberg, E.; Kluss, J.H.; Saez-Atienzar, S.; Landeck, N.; Kumaran, R.; Mamais, A.; Bleck, C.K.E.; et al. LRRK2 mediates tubulation and vesicle sorting from lysosomes. Sci. Adv. 2020, 6, eabb2454. [CrossRef]

132. Südhof, T.C. The Presynaptic Active Zone. Neuron 2012, 75, 11-25. [CrossRef]

133. Mungenast, A.E. Diacylglycerol Signaling Underlies Astrocytic ATP Release. Neural Plast. 2011, 2011. [CrossRef] [PubMed]

134. Bohmbach, K.; Schwarz, M.K.; Schoch, S.; Henneberger, C. The structural and functional evidence for vesicular release from astrocytes in situ. Brain Res. Bull. 2018, 136, 65-75. [CrossRef]

135. Buscemi, L.; Ginet, V.; Lopatar, J.; Montana, V.; Pucci, L.; Spagnuolo, P.; Zehnder, T.; Grubišić, V.; Truttman, A.; Sala, C.; et al. Homer1 Scaffold Proteins Govern Ca2+ Dynamics in Normal and Reactive Astrocytes. Cereb. Cortex 2017, 27, 2365-2384. [CrossRef]

136. Paquet, M.; Ribeiro, F.M.; Guadagno, J.; Esseltine, J.L.; Ferguson, S.S.; Cregan, S.P. Role of metabotropic glutamate receptor 5 signaling and homer in oxygen glucose deprivation-mediated astrocyte apoptosis. Mol. Brain 2013, 6, 9. [CrossRef] [PubMed]

137. Foa, L.; Gasperini, R. Developmental roles for Homer: More than just a pretty scaffold. J. Neurochem. 2009, 108. [CrossRef]

138. Kennedy, M.J.; Ehlers, M.D. Mechanisms and Function of Dendritic Exocytosis. Neuron 2011, 69, 856-875. [CrossRef]

139. Perin, M.S.; Fried, V.A.; Mignery, G.A.; Jahn, R.; Südhof, T.C. Phospholipid binding by a synaptic vesicle protein homologous to the regulatory region of protein kinase C. Nat. Cell Biol. 1990, 345, 260-263. [CrossRef] [PubMed]

140. Südhof, T.C. Calcium Control of Neurotransmitter Release. Cold Spring Harb. Perspect. Biol. 2011, 4, a011353. [CrossRef]

141. Mittelsteadt, T.; Seifert, G.; Alvárez-Barón, E.; Steinhäuser, C.; Becker, A.J.; Schoch, S. Differential mRNA expression patterns of the synaptotagmin gene family in the rodent brain. J. Comp. Neurol. 2009, 512, 514-528. [CrossRef]

142. Zhang, Q.; Fukuda, M.; Van Bockstaele, E.; Pascual, O.; Haydon, P.G. Synaptotagmin IV regulates glial glutamate release. Proc. Natl. Acad. Sci. USA 2004, 101, 9441-9446. [CrossRef]

143. Schonn, J.-S.; Maximov, A.; Lao, Y.; Sudhof, T.C.; Sorensen, J.B. Synaptotagmin-1 and -7 are functionally overlapping Ca ${ }^{2+}$ sensors for exocytosis in adrenal chromaffin cells. Proc. Natl. Acad. Sci. USA 2008, 105, 3998-4003. [CrossRef]

144. Gustavsson, N.; Lao, Y.; Maximov, A.; Chuang, J.-C.; Kostromina, E.; Repa, J.; Li, C.; Radda, G.K.; Südhof, T.C.; Han, W. Impaired insulin secretion and glucose intolerance in synaptotagmin-7 null mutant mice. Proc. Natl. Acad. Sci. USA 2008, 105, 3992-3997. [CrossRef] [PubMed]

145. Gustavsson, N.; Wei, S.-H.; Hoang, D.N.; Lao, Y.; Zhang, Q.; Radda, G.K.; Rorsman, P.; Südhof, T.C.; Han, W. Synaptotagmin-7 is a principal $\mathrm{Ca} 2+$ sensor for Ca2+-induced glucagon exocytosis in pancreas. J. Physiol. 2009, 587, 1169-1178. [CrossRef]

146. Martinez, I.; Chakrabarti, S.; Hellevik, T.; Morehead, J.; Fowler, K.; Andrews, N.W. Synaptotagmin VII Regulates Ca ${ }^{2+}$-Dependent Exocytosis of Lysosomes in Fibroblasts. J. Cell Biol. 2000, 148, 1141-1150. [CrossRef] [PubMed]

147. Luo, F.; Bacaj, T.; Südhof, T.C. Synaptotagmin-7 Is Essential for $\mathrm{Ca}^{2+}$-Triggered Delayed Asynchronous Release But Not for $\mathrm{Ca}^{2+}$-Dependent Vesicle Priming in Retinal Ribbon Synapses. J. Neurosci. 2015, 35, 11024-11033. [CrossRef]

148. Sreetama, S.C.; Takano, T.; Nedergaard, M.; Simon, S.; Jaiswal, J.K. Injured astrocytes are repaired by Synaptotagmin XI-regulated lysosome exocytosis. Cell Death Differ. 2015, 23, 596-607. [CrossRef] [PubMed]

149. Oh, S.-J.; Han, K.-S.; Park, H.; Woo, D.H.; Kim, H.Y.; Traynelis, S.F.; Lee, C.J. Protease activated receptor 1-induced glutamate release in cultured astrocytes is mediated by Bestrophin-1 channel but not by vesicular exocytosis. Mol. Brain $2012,5,38$. [CrossRef]

150. Stenovec, M.; Lasič, E.; Božić, M.; Bobnar, S.T.; Stout, R.F.; Grubišić, V.; Parpura, V.; Zorec, R. Ketamine Inhibits ATP-Evoked Exocytotic Release of Brain-Derived Neurotrophic Factor from Vesicles in Cultured Rat Astrocytes. Mol. Neurobiol. 2016, 53, 6882-6896. [CrossRef]

151. Dai, H.; Shin, O.-H.; Machius, M.; Tomchick, D.; Südhof, T.C.; Rizo, J. Structural basis for the evolutionary inactivation of Ca ${ }^{2+}$ binding to synaptotagmin 4. Nat. Struct. Mol. Biol. 2004, 11, 844-849. [CrossRef]

152. Rusakov, D. Disentangling calcium-driven astrocyte physiology. Nat. Rev. Neurosci. 2015, 16, 226-233. [CrossRef] [PubMed]

153. Hazell, A.S.; Wang, N. Identification of complexin II in astrocytes: A possible regulator of glutamate release in these cells. Biochem. Biophys. Res. Commun. 2011, 404, 228-232. [CrossRef]

154. Wang, Z.; Wei, X.; Liu, K.; Zhang, X.; Yang, F.; Zhang, H.; He, Y.; Zhu, T.; Li, F.; Shi, W.; et al. NOX2 deficiency ameliorates cerebral injury through reduction of complexin II-mediated glutamate excitotoxicity in experimental stroke. Free. Radic. Biol. Med. 2013, 65, 942-951. [CrossRef] [PubMed]

155. Burgoyne, R.D.; Handel, S.E. Activation of exocytosis by GTP analogues in adrenal chromaffin cells revealed by patch-clamp capacitance measurement. FEBS Lett. 1994, 344, 139-142. [CrossRef]

156. Fernandez, J.M.; Neher, E.; Gomperts, B.D. Capacitance measurements reveal stepwise fusion events in degranulating mast cells. Nat. Cell Biol. 1984, 312, 453-455. [CrossRef]

157. Regazzi, R.; Li, G.; Ullrich, S.; Jaggi, C.; Wollheim, C.B. Different requirements for protein kinase C activation and Ca ${ }^{2+}$ independent insulin secretion in response to guanine nucleotides. J. Biol. Chem. 1989, 264, 9939-9944. [CrossRef]

158. Li, G.; Han, L.; Chou, T.-C.; Fujita, Y.; Arunachalam, L.; Xu, A.; Wong, A.; Chiew, S.-K.; Wan, Q.; Wang, L.; et al. RalA and RalB Function as the Critical GTP Sensors for GTP-Dependent Exocytosis. J. Neurosci. 2007, 27, 190-202. [CrossRef]

159. Wu, B.; Guo, W. The Exocyst at a Glance. J. Cell Sci. 2015, 128, 2957-2964. [CrossRef] 
160. Rivera-Molina, F.; Toomre, D. Live-cell imaging of exocyst links its spatiotemporal dynamics to various stages of vesicle fusion. J. Cell Biol. 2013, 201, 673-680. [CrossRef]

161. Zorec, R.; Verkhratsky, A.; Rodríguez, J.; Parpura, V. Astrocytic vesicles and gliotransmitters: Slowness of vesicular release and synaptobrevin2-laden vesicle nanoarchitecture. Neuroscience 2016, 323, 67-75. [CrossRef]

162. Lepore, D.; Martínez-Núñez, L.; Munson, M. Exposing the Elusive Exocyst Structure. Trends Biochem. Sci. 2018, 43, 714-725. [CrossRef] [PubMed]

163. Liu, J.; Zuo, X.; Yue, P.; Guo, W. Phosphatidylinositol 4,5-Bisphosphate Mediates the Targeting of the Exocyst to the Plasma Membrane for Exocytosis in Mammalian Cells. Mol. Biol. Cell 2007, 18, 4483-4492. [CrossRef]

164. Morgera, F.; Sallah, M.R.; Dubuke, M.L.; Gandhi, P.; Brewer, D.N.; Carr, C.M.; Munson, M. Regulation of exocytosis by the exocyst subunit Sec6 and the SM protein Sec1. Mol. Biol. Cell 2012, 23, 337-346. [CrossRef] [PubMed]

165. Moulson, A.J.; Squair, J.W.; Franklin, R.J.M.; Tetzlaff, W.; Assinck, P. Diversity of Reactive Astrogliosis in CNS Pathology: Heterogeneity or Plasticity? Front. Cell. Neurosci. 2021. [CrossRef] [PubMed]

166. Nosi, D.; Lana, D.; Giovannini, M.; Delfino, G.; Zecchi-Orlandini, S. Neuroinflammation: Integrated Nervous Tissue Response through Intercellular Interactions at the "Whole System" Scale. Cells 2021, 10, 1195. [CrossRef]

167. Escartin, C.; Galea, E.; Lakatos, A.; O'Callaghan, J.P.; Petzold, G.C.; Serrano-Pozo, A.; Steinhäuser, C.; Volterra, A.; Carmignoto, G.; Agarwal, A.; et al. Reactive astrocyte nomenclature, definitions, and future directions. Nat. Neurosci. 2021, 24, 312-325. [CrossRef]

168. Liddelow, S.A.; Guttenplan, K.A.; Clarke, L.E.; Bennett, F.C.; Bohlen, C.J.; Schirmer, L.; Bennett, M.L.; Münch, A.E.; Chung, W.S.; Petersong, T.C.; et al. Neurotoxic reactive astrocytes are induced by activated microglia. Nature 2017, 541, 481-487. [CrossRef] [PubMed]

169. Liddelow, S.A.; Barres, B.A. Reactive Astrocytes: Production, Function, and Therapeutic Potential. Immunity 2017, 46, 957-967. [CrossRef]

170. Peng, H.; Erdmann, N.; Whitney, N.; Dou, H.; Gorantla, S.; Gendelman, H.E.; Ghorpade, A.; Zheng, J. HIV-1-infected and/or immune activated macrophages regulate astrocyte SDF-1 production through IL-1ß. Glia 2006, 54, 619-629. [CrossRef]

171. Zheng, J.C.; Huang, Y.; Tang, K.; Cui, M.; Niemann, D.; Lopez, A.; Morgello, S.; Chen, S. HIV-1-infected and/or immune-activated macrophages regulate astrocyte CXCL8 production through IL-1 $\beta$ and TNF- $\alpha$ : Involvement of mitogen-activated protein kinases and protein kinase R. J. Neuroimmunol. 2008, 200, 100-110. [CrossRef]

172. Álvarez, S.; Blanco, A.; Fresno, M.; Muñoz-Fernández, M. Ángeles Nuclear factor-kB activation regulates cyclooxygenase-2 induction in human astrocytes in response to CXCL12: Role in neuronal toxicity. J. Neurochem. 2010, 113, 772-783. [CrossRef]

173. Lau, L.T.; Yu, A.C.-H. Astrocytes Produce and Release Interleukin-1, Interleukin-6, Tumor Necrosis Factor Alpha and InterferonGamma Following Traumatic and Metabolic Injury. J. Neurotrauma 2001, 18, 351-359. [CrossRef] [PubMed]

174. Verhoog, Q.P.; Holtman, L.; Aronica, E.; Van Vliet, E.A. Astrocytes as Guardians of Neuronal Excitability: Mechanisms Underlying Epileptogenesis. Front. Neurol. 2020, 11, 11. [CrossRef] [PubMed]

175. Agulhon, C.; Sun, M.-Y.; Murphy, T.; Myers, T.; Lauderdale, K.; Fiacco, T.A. Calcium Signaling and Gliotransmission in Normal vs. Reactive Astrocytes. Front. Pharmacol. 2012, 3, 139. [CrossRef]

176. Pascual, O.; Ben Achour, S.; Rostaing, P.; Triller, A.; Bessis, A. Microglia activation triggers astrocyte-mediated modulation of excitatory neurotransmission. Proc. Natl. Acad. Sci. USA 2012, 109, E197-E205. [CrossRef]

177. Santello, M.; Bezzi, P.; Volterra, A. TNF $\alpha$ Controls Glutamatergic Gliotransmission in the Hippocampal Dentate Gyrus. Neuron 2011, 69, 988-1001. [CrossRef] [PubMed]

178. Takata-Tsuji, F.; Chounlamountri, N.; Do, L.; Philippot, C.; Ducassou, J.N.; Couté, Y.; Ben Achour, S.; Honnorat, J.; Place, C.; Pascual, O. Microglia modulate gliotransmission through the regulation of VAMP2 proteins in astrocytes. Glia 2021, 69, 61-72. [CrossRef]

179. Calì, C.; Marchaland, J.; Regazzi, R.; Bezzi, P. SDF 1-alpha (CXCL12) triggers glutamate exocytosis from astrocytes on a millisecond time scale: Imaging analysis at the single-vesicle level with TIRF microscopy. J. Neuroimmunol. 2008, 198, 82-91. [CrossRef]

180. Canedo, T.; Portugal, C.C.; Socodato, R.; Almeida, T.O.; Terceiro, A.F.; Bravo, J.; Silva, A.I.; Magalhães, J.D.; Guerra-Gomes, S.; Oliveira, J.F.; et al. Astrocyte-derived TNF and glutamate critically modulate microglia activation by methamphetamine. Neuropsychopharmacology 2021. [CrossRef]

181. Habbas, S.; Santello, M.; Becker, D.; Stubbe, H.; Zappia, G.; Liaudet, N.; Klaus, F.; Kollias, G.; Fontana, A.; Pryce, C.R.; et al. Neuroinflammatory TNF $\alpha$ Impairs Memory via Astrocyte Signaling. Cell 2015, 163, 1730-1741. [CrossRef]

182. Gourine, A.V.; Kasymov, V.; Marina, N.; Tang, F.; Figueiredo, M.F.; Lane, S.; Teschemacher, A.G.; Spyer, K.M.; Deisseroth, K.; Kasparov, S. Astrocytes Control Breathing Through pH-Dependent Release of ATP. Science 2010, 329, 571-575. [CrossRef] [PubMed]

183. Angelova, P.R.; Kasymov, V.; Christie, I.; Sheikhbahaei, S.; Turovsky, E.; Marina, N.; Korsak, A.; Zwicker, J.D.; Teschemacher, A.G.; Ackland, G.L.; et al. Functional Oxygen Sensitivity of Astrocytes. J. Neurosci. 2015, 35, 10460-10473. [CrossRef] [PubMed]

184. Marina, N.; Turovsky, E.; Christie, I.N.; Hosford, P.; Hadjihambi, A.; Korsak, A.; Ang, R.; Mastitskaya, S.; Sheikhbahaei, S.; Theparambil, S.M.; et al. Brain metabolic sensing and metabolic signaling at the level of an astrocyte. Glia 2018, 66, 1185-1199. [CrossRef] [PubMed]

185. Byts, N.; Sharma, S.; Laurila, J.; Paudel, P.; Miinalainen, I.; Ronkainen, V.-P.; Hinttala, R.; Törnquist, K.; Koivunen, P.; Myllyharju, J. Transmembrane Prolyl 4-Hydroxylase is a Novel Regulator of Calcium Signaling in Astrocytes. Eneuro 2021, 8, 1-23. [CrossRef] [PubMed] 
186. Gaidin, S.G.; Turovskaya, M.V.; Mal'Tseva, V.N.; Zinchenko, V.P.; Blinova, E.; Turovsky, E.A. A Complex Neuroprotective Effect of Alpha-2-Adrenergic Receptor Agonists in a Model of Cerebral Ischemia-Reoxygenation In Vitro. Biochem. (Moscow) Suppl. Ser. A Membr. Cell Biol. 2019, 13, 319-333. [CrossRef]

187. Lian, H.; Yang, L.; Cole, A.; Sun, L.; Chiang, A.C.-A.; Fowler, S.W.; Shim, D.J.; Rodriguez-Rivera, J.; Taglialatela, G.; Jankowsky, J.L.; et al. NFkB-Activated Astroglial Release of Complement C3 Compromises Neuronal Morphology and Function Associated with Alzheimer's Disease. Neuron 2015, 85, 101-115. [CrossRef]

188. Stephan, A.H.; Barres, B.A.; Stevens, B. The Complement System: An Unexpected Role in Synaptic Pruning During Development and Disease. Annu. Rev. Neurosci. 2012, 35, 369-389. [CrossRef] [PubMed]

189. Stevens, B.; Allen, N.J.; Vazquez, L.E.; Howell, G.R.; Christopherson, K.S.; Nouri, N.; Micheva, K.; Mehalow, A.; Huberman, A.D.; Stafford, B.; et al. The Classical Complement Cascade Mediates CNS Synapse Elimination. Cell 2007, 131, 1164-1178. [CrossRef] 